\title{
South Africa's Grey Diplomats; Visits by South African Warships to Foreign Countries 1946 - 1996
}

\author{
PROF ANDRÉ WESSELS \\ Department of History, University of the Orange Free State, Bloemfontein ${ }^{1}$
}

\section{ABSTRACT}

The primary role of the South African Navy is to defend the Republic of South Africa, its citizens and interests. In times of peace the Navy has an equally important role to play, for example to conduct assistance operations, including diplomatic support. During the first 75 years of the history of the South African Navy (1922-1997), its warships took part in about 70 flag-showing cruises. In this article a review is given of the 68 flag-showing cruises by South Africa's grey diplomats in the years from 1946 (when the South African Naval Forces were reconstituted) to 1996 (i.e. on the eve of the Navy's 75th anniversary). The aim is to ascertain the nature, extent and value of the South African Navy's diplomatic role.

\section{OPSOMMING}

Die primêre taak van die Suid-Afrikaanse Vloot is om die Republiek van Suid-Afrika, die land se inwoners en belange, te beskerm teen enige vorm van buitelandse bedreiging. In vredestyd het die Vloot egter ' $n$ ewe belangrike rol te speel, byvoorbeeld om hulpverleningsoperasies te onderneem, insluitende diplomatieke steun. Oorlogskepe van die Suid-Afrikaanse Vloot het gedurende die Vloot se eerste 75 jaar (1922-1997) ongeveer 70 vlagvertoonvaarte onderneem. In hierdie artikel word 'n oorsig gegee van die 68 vlagvertoonvaarte wat in die jare vanaf 1946 (toe die Suid-Afrikaanse Seemagte geherkonstitueer is)

The author would like to thank all who assisted him in completing the manuscript, in particular Rear-Adm (rtd) P.A. Wijnberg, Cdre (rtd) D.K. Kinkead-Weekes ( $\dagger$ ), Cdre S.K. Stead, Capt. P.S. Barnard, Capt. (rtd) R.C. Cousens, Cdre (rtd) E.W. Jupp, Capt. R.D. Stephen, Capt. W.C. Wessels, Cdr W.M. Bisset, Cdr F.J. du Preez, Cdr S. van Rooyen, Lt-Cdr M.J. Boardman, Ms L. Jooste and Ms R. Geyer. 
tot en met 1996 (met ander woorde die vooraand van die Vloot se 75ste bestaansjaar) deur die Vloot se grys diplomate onderneem is. Die doel is om vas te stel wat presies die aard, omvang en waarde van die Suid-Afrikaanse Vloot se diplomatieke rol is.

\section{INTRODUCTION}

The traditional exchange of diplomats between friendly countries, reciprocal visits by heads of states and cabinet ministers, and holding of summit meetings, are not the only means of strengthening relations between countries. Throughout the ages it has, for example, been the practice of seafaring countries to send warships to one another from time to time; sometimes to take part in joint exercises, but usually to establish better relations or to strengthen ties that already exist. In this regard the South African Navy (SAN) is no exception, and since 1922 South African warships have undertaken about 70 flag-showing cruises, almost all of them in the years between 1946 and 1996.

These visits have nothing to do with "gun-boat diplomacy", i.e. diplomacy backed by the threat of military force. In the world of diplomacy, warships do in fact play a very important role, and the presence of a warship can be the most tangible and visible sign of bilateral and multilateral friendship. When the ships of a navy take part in combined exercises or international humanitarian and peace-keeping missions, those ships can generate mutual trust and understanding, and promote confidence-building measures supported by peace-loving nations across the globe. All this is symbolic, and the signs are well understood internationally. A navy's diplomatic role should therefore not be underestimated. The warships do not merely become floating cocktail-party venues, but diplomatic tools of the highest national value. It is indeed one of the stated aims of the South African Navy to conduct, inter alia, assistance operations, including diplomatic support. ${ }^{2}$

The South African Navy was established on 1 April 1922, and was then known as the South African Naval Service (SANS). ${ }^{3}$ The first vessels of the fledgling navy were the "Hunt" class minesweeper HMS Crozier (which had been converted into a hydrographic survey vessel, and later renamed HMSAS Protea), and the "Mersey" class minesweeping trawlers Foyle (later renamed HMSAS Sonneblom), and HMS Eden (later renamed HMSAS Immortelle). They left Plymouth in England on 28 November 1921, and arrived outside the British naval base at Simon's Town on 11 January 1922, entering the harbour the next day. ${ }^{4}$

The first ever flag-showing cruise undertaken by South African warships took place in July 1929 when HMSAS Immortelle and HMSAS Sonneblom visited Lourenço Marques in Portuguese East Africa (Mozambique). This was a year after the new South African flag

M. Edmonds and G. Mills, Unchartered waters: a review of South Africa's naval options (Johannesburg, 1996), pp. 72-73; "South African Navy mission statement", Navy News 9, Sept. 1990, p.12.

A. Wessels, "Die Suid-Afrikaanse Vloot: verlede, hede en toekoms" (1), Militaria 11(3), 1981, p.10.

A. du Toit, South Africa's fighting ships past and present (Rivonia, 1992), pp. 5-6, 10-11. 
was introduced, a flag that was to be displayed with the Union Jack until $1957 .^{5}$

The great depression (1929-1935) and other factors led to the virtual demise of the SANS. The HMSAS Protea was withdrawn from service in 1933, and the minesweeping trawlers the next year. The SANS was reduced to little more than an organisation in name only, with no warships, and only five officers, twelve ratings and ten civilians as administrative personnel. When the Second World War broke out in September 1939, South Africa did not really have a navy, but soon the SANS was built up again, becoming the Seaward Defence Force (SDF) in January 1940 and the South African Naval Forces (SANF) in August 1942. In the course of the war, South African warships, inter alia, served in the Mediterranean and in the Far East. When the war finally ended, no fewer than 1436 officers and 8896 ratings had served in the country's naval forces, and in the course of the war 87 vessels had been in service, most of them converted trawlers and whalecatchers. ${ }^{6}$ After the cessation of hostilities, the SANF was scaled down drastically, and by 1946 only had three frigates, one minelayer, eleven harbour defence motor launches, and two boom defence vessels. On 1 May 1946 the SANF was reconstituted as a permanent part of the Union Defence Forces, with an authorised establishment of 60 officers and 806 ratings. $^{7}$

What follows is a review of the 68 flag-showing cruises by South African warships in the years from 1946 to 1996, i.e. from just after the Second World War when the SANF was reconstituted, to the eve of the South African Navy's 75th anniversary. The aim is not to give an in-depth analysis of every single cruise, but to ascertain the general nature, extent and value of the South African Navy's diplomatic role. In the 75th birthday year of the Navy people need to be made aware of the role played by the Navy's grey diplomats. For the first time ever all the basic information conserning the SAN's flag-showing cruises are grouped together with the purpose of exploring the extent of the Navy's diplomatic visits. The largest portion of the study is devoted to a review of all the flag-showing cruises. In the concluding section trends are indicated and an evaluation is made.

\section{NORMAL DIPLOMATIC RELATIONS, 1946-1973}

In 1947 the SANF acquired three additional vessels: the "Algerine" class fleet minesweepers HMSAS Rosamund (later renamed HMSAS Bloemfontein) and HMSAS Pelorus

5 Ibid., p.6; Navy News 11, April 1992, p.25. As far as the new flag issue is concerned, see e.g. J.H. le Roux and P.W. Coetzer, Die Nasionale Party 2: Die eerste bewindsjare 1924-1928 (1) (Bloemfontein, 1980), pp. 195296.

6 Wessels, pp. 10-12. See also A. Wessels, "Die opbou van die Unie-Verdedigingsmagte in die tydperk September 1939 tot September 1941", Journal for Contemporary History 19(3), Dec. 1994, pp. 1-22, and A. Wessels, "South Africa and the war against Japan 1941-1945", Military History Journal 10(3), June 1996, pp. 81-90, 120.

7 Du Toit, p. 171. 
(later renamed HMSAS Pietermaritzburg), and the "Flower" class corvette HMSAS Rockrose (later to become the hydrographic survey vessel HMSAS Protea). On their delivery voyage from Britain to South Africa (sailing on 22 November 1947) the three ships visited Gibraltar, as well as Freetown in Sierra Leone (the latter then also still a British possession), and Walvis Bay, arriving in Cape Town on 24 December 1947. ${ }^{8}$ So, for the first time in the period under discussion, South A frican warships visited foreign shores.

Nearly a year later the SANF (based at Salisbury Island in Durban from March 1948) launched its first flag-showing visit from South African shores when in August and September 1948 all three the "Loch" class frigates, HMSAS Good Hope, HMSAS Transvaal and HMSAS Natal, visited Mocãmedes (today Namibe), Lobito and Luanda in the Portuguese colony Angola, and Matadi in the Belgian Congo (later known as Zaire, and today as the Democratic Republic of the Congo). ${ }^{9}$ Shortly afterwards, in November 1948, the frigate HMSAS Natal and minesweepers HMSAS Bloemfontein and HMSAS Pietermaritzburg visited Lourenço Marques (the present-day Maputo), Inhambane and Beira in Mozambique, Portugal's second largest colony in Africa. The ships all arrived back in Durban on 12 December $1948 .{ }^{10}$

Towards the end of 1950 the SANF (to be known as the South African Navy or SAN from 1 January 1951), embarked on the most ambitious diplomatic exercise since its inception, when on 26 December 1950 the frigate HMSAS Transvaal left Durban on its way to Australia, under the command of Lt-Cdr James Johnson (later chief of the SAN). After calling at the meteorological station on Amsterdam Island (to this day still a French possession), South Africa's grey diplomat arrived at Fremantle on 10 January 1951. From there the ship sailed to Sydney, to take part in the Australian Jubilee Celebration which lasted for two weeks. On arrival in Sydney on 29 January, the Transvaal took part in a screening and manoeuvring exercise with units of the Royal Australian, Royal New Zealand, British, Indian and Pakistani navies. Later that afternoon, HM Submarine Tactician was placed at Transvaal's disposal for anti-submarine exercises. The South African ships subsequently visited Jervis Bay, Melbourne, Adelaide and, for a second time, Fremantle, before returning to South Africa (arriving back in Durban on 4 March 1951) - minus seven of her crew, who went AWOL! (Four left in Melbourne, two in Adelaide and one in Fremantle. Five had been offered lucrative and promising employment opportunities, while two had fallen in love!) $)^{11}$

Ibid., pp. 183, 188. The ships' log-books for this particular period are missing. This also applies to several other voyages undertaken by other ships in the years 1947-1972. The reports of proceedings for cruises undertaken in the years 1946-1996 are also not always available.

9 Du Toit, p. 161.

10 Ibid., p. 184; The Natal Mercury, 29.11.1948 and 13.12.1948. Some of the newspaper articles were consulted in the form of cuttings, in which case the page numbers are not always available.

11 Du Toit, p. 161; Navy News 11, April 1992, p. 25; Commando 2(12), May 1951, pp. 4-7, 39 and 2(15), Aug. 1951,pp. 4-7. 
On 29 March 1950 the SANF took delivery of its first destroyer when HMSAS Jan van Riebeeck (formerly the "Wager" class destroyer HMS Wessex), was handed over at Simon's Town, followed on 23 February 1953 by SAS Simon van der Stel (formerly also a "Wager" class destroyer, HMS Whelp). On 20 June 1952 the prefix of all South African naval vessels were changed from HMSAS to SAS, symbolising the growing Afrikaner nationalism since the National Party came to power in 1948. But, for the time being at any rate, the new government's apartheid policy did not affect the Navy's diplomatic role. In the course of the second half of 1952, SAS Jan van Riebeeck, SAS Transvaal and SAS Bloemfontein went on a month-long cruise to East African ports. The task force sailed from Durban on 24 August 1952 and visited Diégo Suarez in Madagascar (then still French territory) from 30 August to 1 September, Mombasa (Kenya) from 4 to 6 September, and Dar es Salaam (Tanganyika - today Tanzania) from 7 to 8 September - the latter two then still British possessions. The ships arrived back in Durban on 13 September. ${ }^{12}$

Two years later, SAS Simon van der Stel left South African shores on an extended overseas visit. The main reason for sending a South African warship all the way to Europe (the first time since the Second World War), was to escort SAS Gelderland (ex HMS Brayford), the first of five "Ford" class seaward defence boats (SDB's) acquired by the Navy, to South Africa. However, this afforded the Navy a golden opportunity to show the South African flag in European waters, as well as along the west coast of Africa. Under the command of Cdr M.R. Terry Lloyd, the Simon van der Stel left Durban on 14 July 1954. Also on board were the Gelderland's crew and a few marines. The ship visited Cape Town, Walvis Bay (then, of course, still part of South Africa), Freetown and Dakar (in Senegal, then still French territory), arriving in Portsmouth on 31 July, and berthing alongside the battleship HMS Vanguard which in 1947, had brought the British Royal Family to South Africa. After a stay of some two weeks, the Simon van der Stel became the first ever South African warship to visit the Netherlands, berthing in Rotterdam from 18 to $23 \mathrm{Au}$ gust. From there the destroyer sailed back to Portsmouth, then to Londonderry in Northern Ireland, up the River Clyde to Glasgow, and back again to Portsmouth. On 21 October the Simon van der Stel and Gelderland left the Royal Navy base and sailed home via Brest (France), Lisbon (Portugal), Las Palmas (Canary Islands, a Spanish possession), Dakar, Abidjan (then still part of French West Africa; today in Côte d 'Ivoire, i.e. the Ivory Coast), Pointe Noire (then still in French Equatorial Africa; today in the Republic of the Congo), Walvis Bay, Cape Town and Port Elizabeth, arriving back in Durban on 8 December 1954 after 147 days and sailing about 17200 nautical miles. ${ }^{13}$ To date, this is the longest time

12 Du Toit, pp. 172, 193, 195; log-book: SAS Jan van Riebeeck. All the log-books referred to in this article are kept by the Documentation Service Directorate (Group 5) of the South African National Defence Force in Pretoria. Information obtained with the kind assistance of Ms L. Jooste and Ms R. Geyer.

13 Du Toit, pp. 195-196; Navy News 9, Jan.-Feb. 1991, p. 22 and March 1991, p. 17; Navy News 10, April-May 1991, p. 18; Nederlandsch Zuid-Afrikaansche Vereeniging (NZAV) Archives (Amsterdam), NZAV VI 1091 : several letters. 
that any South African warship has been away from home in peacetime.

The following year the frigates SAS Good Hope (newly commissioned under Lt-Cdr R.C. Cousens after being converted into a despatch vessel and at that stage the flagship of the South African Navy) and SAS Transvaal paid a diplomatic visit to Madagascar. On board the Good Hope was Dr the Hon. E.G. Jansen, Governor-General of South Africa, and his wife, Mabel. It was the first (and to date the last) time that a South African head of state travelled to another country in a South African warship. The ships left Durban on 22 July 1955 and visited Nossi Bé, Diégo Suarez and Tamatava. The recently formed Naval Band was embarked for the first time, as was the Chief of Naval and Marine Staff, Cdre H.H. Biermann. ${ }^{14}$

In the meantime, negotiations between the South African and British governments on the future of the Royal Navy base at Simon's Town began in London on 1 September 1954. The South African minister of Defence, Mr F.C. Erasmus, made a formal request for the transfer of the base to South Africa. The negotiations were continued in Pretoria and Simon's Town, and lasted until November 1954. The following year the basic agreement was concluded, and the formal transfer took place on 2 April 1957, giving the South African Navy the time to train personnel to man the highly technical installations. In accordance with the Simon's Town Agreement, Britain and her allies could still use the base facilities, and South Africa undertook to expand its Navy by purchasing six destroyers and/or frigates, ten coastal minesweepers and four SDB's. Ships already bought from 1954 onwards, or on order, would form part of the expansion. Eventually, the SAN would acquire all the minesweepers and five SDB's, but only four frigates. ${ }^{15}$

As already described, the SDB SAS Gelderland had arrived in South Africa in 1954, escorted by SAS Simon van der Stel. The new coastal minesweepers and other SDB's arrived in groups of two or three in South African waters in the course of the next five years, not escorted by any larger warships. The minesweepers SAS Kaapstad (ex HMS Hazleton, under the command of Lt W.J.J. Hutchinson) and SAS Pretoria (ex HMS Dunkerton, Lt-Cdr P. Selk) - the latter ship since 1987 a private museum ship in Hout Bay - sailed from Portsmouth on 4 October 1955, together with the SDB SAS Nautilus (ex HMS Glassford, Lt D.F. Silberbauer; since the early 1990's a private luxury yacht), and arrived in Durban on 22 November, visiting Lisbon (7-9 October), Las Palmas (11-13 October), Dakar (16-19 October), Abidjan (23-25 October), Pointe Noire (29 October1 November), Walvis Bay (9-10 November), Cape Town (13-17 November), Port Elizabeth (18-20 November), and East London (20-21 November) on passage. Next to sail for

14 Information supplied by Rear Adm. (rtd) P.A. Wijnberg; Navy News 6(2), 1987, p. 13; Du Toit, p. 163.

15 A. Wessels, "Die Simonstadse Ooreenkoms", Yesterday and Today 14, Sept. 1987, pp. 18-21; Die Transvaler, 3.4.1957, pp. 1, 6, 7; The Cape Argus, 3.4.1957, p. 11; Die Burger, 2.4.1957, pp. 1, 8, 9 and 3.4.1957, pp. 1, 5, $7,9,15$; P.J. Henshaw, "The transfer of Simonstown: Afrikaner nationalism, South African strategic dependence, and British global power", The Journal of Imperial and Commonwealth History 20(3), Sept. 1992, pp. 420-444; J.C. Goosen (compiler), Ons Vloot: die eerste vyftig jaar (Johannesburg, 1973), pp. 135-150. 
South Africa were the minesweepers SAS Durban (under the command of Lt-Cdr E.W. Jupp) - since 1988 a private museum ship in Durban harbour - and SAS Windhoek (LtCdr R.D. Kingon). They left Portsmouth on 12 May 1958 and arrived in Simon's Town on 13 June, showing the South African flag at Lisbon (arrived on 15 May), Las Palmas (arrived on 19 May), Dakar (arrived on 24 May), Abidjan (arrived on 30 May), Pointe Noire (arrived on 4 June), Lobito (arrived on 6 June) and Walvis Bay (arrived on 9 June). In November of that same year the minesweepers SAS East London (ex HMS Chilton, under the command of Lt-Cdr C.J.F. Netterberg) and SAS Port Elizabeth (ex HMS Dumbleton, Lt-Cdr E.M. Kramer) and the SDB SAS Rijger (Lt. B. Duncum) sailed to South Africa, visiting Lisbon, Las Palmas, Dakar, Pointe Noire, Lobito and Walvis Bay en route, and arriving in Simon's Town on 21 December 1958. ${ }^{16}$

In the course of the latter part of 1959, the last of the new minesweepers and SDB's arrived in Simon's Town. The minesweepers SAS Johannesburg (ex HMS Castleton, under the command of Lt-Cdr T.F. Shenfield) and SAS Kimberley (ex HMS Stratton, Lt-Cdr P.W. Cowburn), and the SDB SAS Haerlem (Lt D.B.Reaper) left Portsmouth on 14 July 1959, and sailed via Lisbon (17-19 July), Las Palmas (21-23 July), Dakar (26-28 July), Abidjan (1-3 August), Pointe Noire (7-9 August), Lobito (11-13 August) and Walvis Bay (16-18 August) to Simon's Town, arriving on 21 August. The ninesweepers SAS Mosselbaai (ex HMS Oakington, Cdr B. Grindley) and SAS Walvisbaai (ex HMS Packington, Lt-Cdr A.C. McMurray), and the SDB SAS Oosterland (Lt A.S. Davis) left Portsmouth on 30 October 1959, and sailed via Lisbon (2-4 November), Las Palmas (6-8 November), Dakar (11-13 November), Abidjan (17-19 November), Pointe Noire (23-25 November) and Walvis Bay (29 November- 2 December) to Simon's Town, arriving on 5 December. ${ }^{17}$

In the meantime the South African Navy had also acquired a former Royal Navy "W" class detroyer HMS Wrangler, converted into an anti-submarine frigate. Commissioned into the Navy at Cardiff on 29 November 1956 as SAS Vrystaat, the ship also visited Portland and Devonport (Plymouth), being handed over officially to the SAN at the latter port on 10 January 1957. The Vrystaat sailed from Devonport on 22 January 1957 and visited Lisbon (25-27 January), Gibraltar (28-30 January), Las Palmas (1-3 February), Freetown (7 February), Luanda (13-15 February) and Cape Town (19-21 February) on her way to Durban, where she arrived on 23 February. ${ }^{18}$

Shortiy after the arrival of the Vrystaat, the South African Navy took over the Simon's Town Naval Base and Dockyard from the Royal Navy, and the South African warships

16 Du Toit, pp. 211-212; The Cape Argus, 13.6.1958, p.1; Commando 9(8), Aug. 1958, pp. 22-23; S.A. Naval Museum: History of the mine countermeasures flotilla 1922-1988 (unpublished manuscript), pp. 23, 25-26.

17 Information supplied by Capt. P.S. Barnard; Du Toit, p. 212; Die Burger, 22.8.1959, p. 7 and 24.9.1959, p. 9; S.A. Naval Museum: History of the mine countermeasures flotilla 1922-1988 (unpublished manuscript), p. 26; log-books: SAS Johannesburg, SAS Kimberley, SAS Walvisbaai.

18 Du Toit, p. 202; log-book: SAS Vrystaat. 
were moved from Salisbury Island in Durban to their new base. The base in Durban was closed but was later progressively reactivated and modernised from 1972 onwards, in due course once again becoming a full-fledged naval base..$^{19}$

The first South African flag-showing visit to be launched from its new naval base, was undertaken in July and August 1957 by a task force consisting of the frigates SAS Good Hope (Lt-Cdr R.C. Cousens) and SAS Vrystaat (Capt. M.R. Terry Lloyd), and the minesweepers SAS Kaapstad (Lt-Cdr E.W. Jupp) and SAS Pretoria (Lt-Cdr R.D. Kingon). The squadron was under the overall command of Rear-Adm. H.H. Biermann (the newly promoted Naval Chief), flying his flag in Good Hope. This was the first time that a South African warship had flown the flag of a South African admiral at sea. The ships left Simon's Town on 12 July 1957, visited Durban (15-16 July), Lourenço Marques (17-23 July) and Beira (23-25 July). From Beira, the Vrystaat sailed to Mombasa in Kenya (staying in port 28-30 July), to fetch ammunition that had been bought from the British government. The rest of the squadron returned to Simon's Town via Durban (29 July), arriving back on 2 August. The Vrystaat arrived back in Simon's Town on 7 August, after also paying a visit to Durban (2-5 August). The voyage, which had taken place at the invitation of the Portuguese government, was a great success and more than ever before the South African government realised that the Navy could be used as a very effective ambassador. ${ }^{20}$

Two years later, in August 1959, Rear-Adm. H.H. Biermann once again flew his flag in SAS Good Hope (now with Cdr P. Selk as her captain), when that ship and SAS Vrystaat (still under Capt. M.R. Terry Lloyd) visited Luanda in Angola and the Belgian Congo. They sailed about $150 \mathrm{~km}$ up the mighty Congo River to Matadi, and on their way back to the Atlantic Ocean, the Vrystaat set up a record for the fastest passage from Matadi to the port of Banana. The Vrystaat sailed back first, because Lt-Cdr E.M. Kramer (from the Good Hope) developed appendicitis, and was transferred to the bigger and faster ship. The Vrystaat arrived back in Cape Town on 10 September 1959..21

The Navy's next flag-showing cruise took SAS Vrystaat (now under Capt. J. Fairbairn) back to Europe - the first South African visit in six years. The occasion was the 500th anniversary of the death of Portugal's Prince Henry the Navigator. The Vrystaat left Simon's Town on 18 July 1960, visited Walvis Bay (20 July), Freetown (27 July), Gibraltar (2-5 August), and arrived in Lagos, Portugal, on 6 August. The next day, 35 warships from twenty countries took part in a naval review at Lagos, near the south-eastern tip of Portugal, followed by a sail-past at Sagres Point, and the unveiling of the Monument to the

Du Toit, pp. 174, 176.

Commando 8(7), July 1957, p. 4 and 8(9), Sept. 1957, p. 31; Goosen, p. 195; Du Toit, pp. 163, 213; S.A. Naval Museum: History of the mine countermeasures flotilla 1922-1988 (unpublished manuscript), p.23; log-books: SAS Vrystaat, SAS Pretoria. From the consulted sources it becomes clear that the task-force did not always stay together, but that the smaller and slower minesweepers sometimes arrived later and/or departed earlier than the faster frigates; e.g. SAS Pretoria left Lourenço Marques on 21 July and arrived in Beira on 24 July. The logbooks of the Good Hope and Kaapstad for this period could not be traced.

Du Toit, pp. 163, 202. 
Discoveries at Belem, on the banks of the River Tagus. It was from there that many seafarers had set out on their voyages of discovery. South Africa's gift to Portugal was the "compass rose" which forms the forecourt of the monument. The Vrystaat arrived in Lisbon on 8 August, sailed on 11 August, and visited Las Palmas (13-15 August), Freetown (20 August) and Walvis Bay (29 August) on passage to Simon's Town, arriving back on 9 September 1960. By 1960, thanks to the Vrystaat's successful trip to Europe, the visits to several foreign ports by the new ships on their respective maiden voyages, and the order placed for the building of three modern frigates, the South African Navy had moved away from the old adage which used to be a lower-deck joke: "SANF - Saldanha And No Further!".22

The year 1960 was a turbulent year in the history of South Africa. The most important events included British prime minister Harold Macmillan's "Wind of change" speech in the South African parliament on 3 February, the events at Sharpeville on 21 March and in other so-called townships, the banning of the African National Congress (ANC) and PanAfricanist Congress (PAC) on 8 April, and the referendum held on 5 October during which the white voters by a small majority voted in favour of their country becoming a republic. On 31 May 1961 South Africa became a republic outside the British Commonwealth. The prime minister, Dr H.F. Verwoerd, had gone to Britain with the idea of requesting permission for South Africa to remain in the Commonwealth, but its representatives sharply criticised his government's apartheid policy, and he withdrew South Africa's application for membership on 15 March 1961. This event, as well as other factors, gradually led to South Africa's growing isolation, including military isolation, which in turn had serious implications for the procurement of military hardware (especially naval vessels) and - in due course - limited flag-showing possibilities. For the time being, however, there seemed to be no problems.

The first flag-showing cruise conducted by the Navy for the new Republic of South Africa (RSA), took SAS Vrystaat (Capt. J. Fairbairn) to Lourenço Marques in mid-1961. ${ }^{23}$ Then followed the delivery voyages of each of the three new Type 12 frigates built in Britain for the South African Navy, at 2557 tons full load and with a length of $112,78 \mathrm{~m}$ the largest combat vessels built for the Navy to date. The first ship, SAS President Kruger ("PK"), was commissioned at Scotstoun, Glasgow, on 3 October 1962, with Capt. M.R. Terry Lloyd as her commanding officer. The frigate sailed to Portsmouth for the tuning and testing of her equipment, and was declared a fully operational fighting unit on 14 February 1963. She then departed from Portsmouth on 27 February, showing the South African flag at Lisbon (2-4 March), Gibraltar (5-7 March), Las Palmas (9-10 March),

22 Information supplied by Cdr W.M. Bisset; Goosen, p. 196; Du Toit, p. 202; SA.NDF Documentaton Service Directorate (Pretoria), Chief of Naval Staff, 273: Operations. Movements, docking and refits - non-routine movements. Visit to Portugal. 500th anniversary, death of Prince Henry the Navigator, Aug. 1960.

23 Goosen; p. 196; Du Toit, p. 202. 
Luanda (20-22 March) and Saldanha Bay (27 March) on passage to Simon's Town, where she arrived on 28 March $1963 .{ }^{24}$

South Africa's second new frigate, SAS President Steyn ("PS"), was commissioned at Linthouse, Glasgow, on 8 April 1963, left Portsmouth on 17 August 1963, and arrived at Simon's Town on 13 September 1963, having called at Lisbon (19-21 August), Gibraltar (22-24 August), Las Palmas (26-28 August), Luanda (6-8 September) and Saldanha Bay (12-13 September) on passage to her base. ${ }^{25}$ SAS President Pretorius ("PP"), the third and final unit of the "President" class, was commissioned at Scotstoun, Glasgow, on 18 March 1964, with Capt. J. Johnson as her commanding officer. The ship also sailed to Portsmouth for tuning and testing of equipment, and for work-up at Portland. The maiden voyage was, as customary, used to show the South African flag at foreign ports. Leaving Portsmouth on 29 August 1964, SAS President Pretorius visited Lisbon (31 August-3 September), Gibraltar (4-5 September), Las Palmas (7-9 September), Luanda (18-21 September) and Saldanha Bay (25-26 September), arriving in Cape Town on 26 September, before sailing to Simon's Town. ${ }^{26}$

After the acquisition of the three new frigates, the old frigates Vrystaat, Transvaal and Good Hope were paid off into reserve in 1963, 1964 and 1965 respectively, never to be commissioned again. The Vrystaat was eventually expended as a submarine target on 14 April 1976, while the Good Hope and Transvaal were both sunk as artificial reefs at Smitswinkel Bay, on 12 June 1978 and 3 August 1978 respectively. In the meantime, from 1962 to 1966, the destroyers Simon van der Stel and Jan van Riebeeck were extensively modified and converted into helicopter-carrying anti-submarine ships, each equipped with two Wasp anti-submarine helicopters. The Simon van der Stel eventually paid off into reserve in 1972 and was broken up in Durban in 1976, while the Jan van Riebeeck paid off into reserve in 1975 and was expended as a missile target in 1980. ${ }^{27}$

After the arrival of "PP" in 1964, three years passed before the South African Navy embarked on a new series of diplomatic initiatives. The first cruise was to South American waters, never before visited by South African warships. On 24 October 1967 SAS President Kruger (under the command of Capt. D.K. Kinkead-Weekes) and SAS President Pretorius (Capt. A.C. McMurray) left Simon's Town and were joined off Cape Town by the newly-acquired replenishment vessel, SAS Tafelberg (Capt. R.C. Cousens), under the overall command of Cdre James Johnson, Senior Officer of the 10th Frigate Squadron. The task force arrived at Puerto Belgrano in Argentina on 6 November, sailed on 9 November, visited Buenos Aires (staying 11-15 November), and held exercises with destroyers of the Argentinian Navy. The destroyers were the San Luis, Misiones and Buenos

Du Toit, p. 222; Commando 14(5), May 1963, pp. 20-23; Log-book: SAS President Kruger.

Du Toit, pp. 223-224; log-book: SAS President Steyn.

Du Toit, pp. 223-224; log-book: SAS President Pretorius.

Du Toit, pp. 165-167, 196-197, 203-205. 
Aires. The task-force arrived back in Simon's Town on 27 November. The Tafelberg proved her value during this cruise. She not only became the Navy's largest grey diplomat ever, but for the next 25 years would also assist other units of the SAN to fulfill their diplomatic role even better, e.g. by replenishing them at sea and thus enabling them to sail further afield than ever before..$^{28}$

In the meantime, the minesweepers SAS Kimberley (Lt-Cdr D.B. Reaper) and SAS Mosselbaai (Lt-Cdr C.H. Bennett) visited Luanda in October 1967. They left Simon's Town on 16 October 1967, arrived in Cape Town the next day, took on board the stores and equipment they were to ship to Luanda, and arrived in Walvis Bay on 19 October and in Luanda on 22 October. They departed on 25 October, visited Walvis Bay once again (28 October) and were back in Simon's Town on 31 October. In their role as grey diplomats, small vessels could sometimes be as important as big warships. ${ }^{29}$

October 1968 once again saw the launching of two important diplomatic missions by warships of the RSA. Nearly three decades after HMSAS Transvaal showed the Union's flag in Australian waters, a task force left Simon's Town on 7 October 1968 for the long voyage across the Indian Ocean to Australia: SAS President Steyn (Capt. D.K. KinkeadWeekes), SAS President Pretorius (Capt. A.C. McMurray) and SAS Tafelberg (Capt. R.C. Cousens) - all, once again, under the overall command of Cdre James Johnson. The Tafelberg had a total crew of 125 , while each of the frigates had 238 men on board. The squadron arrived in Fremantle on 23 October and left again on 26 October, sailing to Sydney, where the ships arrived on 2 November. From there the task force left again on 8 November and sailed to Melbourne (10-14 November), and from there back to Fremantle, where the two frigates berthed on 18 November, while the Tafelberg anchored in the bay'. The SAN task force left on 21 November, and crossed the Indian Ocean back to Simon's Town, where they arrived on 3 December, having been away for 58 days and sailing 14 642 nautical miles. ${ }^{30}$

In the meantime the destroyer SAS Simon van der Stel (Capt. G.N. Brits) and the minesweepers SAS Kimberley (Cdr J.C. Ferris) and SAS Mosselbaai (Lt-Cdr J.A.C. Weideman) visited Lourenço Marques in October 1968 to take part in the unveiling (on 12 October) of the Garden of Remembrance, a memorial to the Voortrekker leader Louis Tregardt. The Kimberley and Mosselbaai sailed from Simon's Town on 4 October and teamed up with the Simon van der Stel in Durban on 7 October. From there all three the

Ibid., pp. 197, 226; information supplied by Cdre (rtd) D.K. Kinkead-Weekes; log-books: SAS President Kruger, SAS Tafelberg. The latter ship joined the frigates on 24 October off Cape Town, having sailed from Simon's Town on 20 October and arriving in Cape Town the next day. Du Toit, pp. 197, 213; S.A. Naval Museum: History of the mine countermeasures flotilla 1922-1988 (unpublished manuscript), pp. 41-42.

30 S.A. Naval Museum: Report of proceedings - visit to Australia - period 7th October to 3rd December, 1968; Du Toit, p. 226; Navy News 8, Dec. 1986, p. 9; Goosen, pp. 197-198; Commando 20(4), Apr. 1969, pp. 13, 15 and 20(5), May 1969, pp. 13, 15, 25. 
ships sailed on 9 October, arrived in Lourenço Marques on 10 October and sailed on 14 October. From 15 October the ships no longer sailed together, with the two minesweepers arriving back in Simon's Town on 17 October 1968. ${ }^{31}$

In October 1969 the destroyer SAS Simon van der Stel (Capt. G.N. Brits), the frigate SAS President Pretorius (Capt. A.C. McMurray), the minesweepers SAS Port Elizabeth (Cdr J.C. Ferris) and SAS Walvisbaai (Lt-Cdr R.A.S. Myers), as well as the replenishment ship SAS Tafelberg (Capt. R.C. Cousens - who was also in overall command), paid courtesy visits to Angolan ports, to cement the already good relations between the RSA and Portugal. On board the ships were a total of 432 officers, warrant officers and ratings. The task force left Simon's Town on 14 October 1969, arrived at Mocãmedes (today Namibe) on 20 October, departed on 22 October and arrived at Luanda on 24 October. After a fourday stay, the grey diplomats left on 28 October, arrived at Lobito the next day, and departed for Simon's Town on 1 November, arriving back home on 5 November. ${ }^{32}$

The next year saw three "Ton" class minesweepers visiting Lourenço Marques. SAS Port Elizabeth (Cdr A.P. Putter), SAS Windhoek (Cdr J.H. Hall) and SAS Johannesburg (Cdr B.E. Harding) left Simon's Town on 10 July 1970, stopped at Durban on 13 July, visited Lourenço Marques from 15 to 18 July, visited Durban once again on 21 July, and were back in Simon's Town on 25 July. ${ }^{33}$

In January 1971 the inaugural Transatlantic yacht race between Cape Town and Rio de Janeiro (Brazil) took place, and SAS Tafelberg (Capt. R.C. Cousens) acted as the guardship. Once again, the Navy could use an opportunity to show the South African flag in South American waters. The Tafelberg departed from Cape Town on 16 January and escorted the yachts across the South Atlantic. Because of political considerations the ship could not enter Rio de Janeiro harbour, and consequently cruised some 60 nautical miles off the harbour until the last yacht had passed the finishing line, and then altered course for Buenos Aires in Argentina, arriving on 23 February and staying until 3 March. After two months and approximately 18000 nautical miles, "Mamma Tafies", as South Africa's first replenishment ship in due course became known affectionately, was back in Cape Town on 15 March 1971, before returning to Simon's Town. The vessel brought back the yachts Voortekker (S.A. Navy) and Active. ${ }^{34}$

In the course of the 1960's, it was decided to acquire submarines for the SAN. Although the British "Oberon" class was the logical choice, the political climate in Britain prohibited that kind of order, and consequently an order for three "Daphne" class submarines were placed with the French yard Dubigeon-Normandie in Nantes. ${ }^{35}$ Each of the

${ }_{31}$ Du Toit, p. 197; Goosen, p. 198; log-book: SAS Mosselbaai.

32 Information supplied by Capt. (rtd) R.C. Cousens; Du Toit, p. 226; Goosen, p. 198; S.A. Naval Museum, newspaper cuttings (file): several cuttings.

33 S.A. Naval Museum: History of the mine countermeasures flotilla 1922-1988 (unpublished manuscript), p.46.

34 Du Toit, p. 242; information supplied by Capt. (rtd) R.C. Cousens.

35 Du Toit, pp. 176, 267. 
submarines would be escorted to South Africa on her maiden voyage by a large surface vessel, and this once again afforded the RSA's grey diplomats the opportunity to visit ports in Europe and along the west coast of Africa; the Suez Canal, of course, having been closed since the 1967 Six Day War, and only opening again in 1975.

On 5 August 1969 SAS President Kruger was recommissioned after undergoing a complex modernisation, which, inter alia, involved the building of a flight deck and hangar for a Wasp anti-submarine helicopter. The President Steyn underwent a similar conversion from 1969 to 1971 , and the President Pretorius was eventually recommissioned on 12 July 1977, after undergoing an even more extensive conversion. On 28 January 1971 SAS President Kruger, under the command of Capt. G.N. Green, left Simon's Town for the Mediterranean, visiting Luanda (1-2 February), Las Palmas (10-12 February) and Lisbon (14-18 February) en route. For the first time since the Second World War, when the salvage vessel HMSAS Gamtoos entered Naples in Italy in 1945 (after clearing the harbour entrance), did a South African warship visit that country. The President Kruger visited Augusta on Sicily (23-24 February) and Naples (26 February-1 March). In Toulon the frigate linked up with the Navy's first submarine, SAS Maria van Riebeeck, which had been commissioned on 24 July 1970 under Cdr J.A.C. Weideman. "PK" arrived in Toulon on 2 March and departed on 24 March, together with the Maria van Riebeeck. During the passage to South Africa, the two naval units visited Gibraltar (29 March-1 April), Porto Grande on São Vicente (St Vincent, in the Cape Verde Islands, 9-12 April), Luanda (26 April-1 May), and Walvis Bay (6-9 May). In the meantime the destroyer SAS Simon van der Stel (Capt. D.F. Silberbauer) visited Lobito in Angola (27-30 April), then joined the replenishment ship SAS Tafelberg (Capt. R.C. Cousens) on the high seas, and they then rendezvoused with the President Kruger and Maria van Riebeeck, conducting exercises from 1 to 3 May. "PK" and Maria van Riebeeck arrived in Simon's Town on 13 May $1971 .^{36}$

The next submarine to be escorted back to South Africa was SAS Emily Hobhouse, commissioned on 26 February 1971, with Lt-Cdr L.J. Woodburne (later chief of the Navy) as her commanding officer. This time it was SAS President Steyn, under the command of Capt. E.W. Jupp, which had the honour of showing the South African flag in the northern hemisphere; as a matter of fact, "PS" would sail further north than any other South African warship had at that stage, and it was not until 1994, when SAS Drakensberg visited several European ports, that a grey diplomat of the RSA would sail even further north. "PS" departed from Simon's Town on 1 September 1971, rendezvoused with SAS Tafelberg on 5 September and sailed in company until 9 September, visiting Lisbon (17-21 September) and Hamburg (25-27 September), sailed through the Kiel Canal to visit Kiel (27-29 September), then sailed to Portsmouth (1-11 October), Portland (11-13 October) and on to

36 Ibid., pp. 226, 242, 271; Goosen, p. 198; information supplied by Capt. (rtd) R.C. Cousens; log-books: SAS President Kruger, SAS Simon van der Stel. 
Toulon (18-26 October) to team up with SAS Emily Hobhouse. On passage to South Africa the vessels visited Cadiz in Spain (30 October-1 November), Porto Grande on St Vincent (Cape Verde Islands, 9-11 November), Luanda (24-28 November) and Walvis Bay (3-5 December), arriving in Simon's Town on 10 December 1971, having been replenished at sea by SAS Tafelberg (Capt. R.C. Cousens) on 16 November, about half-way between the Cape Verde Islands and Luanda, in position Latitude $3^{\circ} .30^{\prime} \mathrm{N}$ Longitude $10^{\circ} \mathrm{W}$. The only incident to mar an otherwise highly successful cruise, was the loss of the frigate's Wasp helicopter near the Luanda Airport on 25 November in a crash in which the pilot and the three others on board were killed. ${ }^{37}$

The Navy's third and final submarine, SAS Johanna van der Merwe, was commissioned at Lorient on 27 August 1971, and was commanded by Lt-Cdr T.J. Honiball. This submarine was to have been accompanied on her maiden voyage by the Navy's new hydrographic research vessel, SAS Protea, then working up in Britain. However, the Protea's departure was delayed because of various delays during her acceptance trials as a result of equipment malfunctions and public holidays, and consequently, SAS President Steyn (Capt. J.J. Nieuwoudt) was once again sent to Europe. "PS" left Simon's Town on 10 April 1972, visited Porto Grande (St Vincent Island, 20 April) and Las Palmas (22-24 April) on passage to Europe, and teamed up with SAS Johanna van der Merwe in Toulon on 28 April. The frigate sailed from Toulon on 4 May, rendezvoused with the submarine the next day, and they then sailed together, visiting Cadiz (8-10 May), Porto Grande (1820 May), Luanda (3-7 June) and Walvis Bay (12-14 June), arriving in Simon's Town on 19 June $1972 .^{38}$ On 23 May 1972 SAS Protea (Capt. Arthur Fawthrop) was commissioned at Scotstoun, Glasgow, and sailed to South Africa after completing a work-up at Portland. The hydrographic research vessel visited Lisbon, Luanda and Walvis Bay on passage to Simon's Town, arriving on 14 July $1972 .{ }^{39}$ Unknown to all concerned at that time, more than twenty years would pass before another South African grey diplomat would visit ports in Europe.

In the meantime, the minesweepers SAS Johannesburg (Lt-Cdr P.R. le Roux), SAS Walvisbaai (Lt-Cdr M.H. Heyns) and SAS Windhoek (Lt-Cdr J.J. van Noordwyk), as well as the diving support and torpedo recovery vessel SAS Fleur (Lt G.G. Schlemmer), visited Durban and Lourenço Marques in the period 15 to 27 May 1972. From 9 to 12 November 1972 SAS Johannesburg (Lt-Cdr P.R. le Roux) and SAS Mosselbaai (Lt-Cdr P.J. Jonker) visited Lobito in Angola. ${ }^{40}$

Information supplied by Cdre S.K. Stead, Capt. (rtd) R.C. Cousens, Cdre (rtd) E.W. Jupp and Cdr W.M. Bisset; Goosen, p. 198; Du Toit, p. 228; log-books: SAS President Steyn, SAS Emily Hobhouse. SAS President Steyn, SAS Johanna van der Merwe.

Du Toit, p. 263; S.A. Naval Museum, SAS Protea (file): brochures, etc.; The Cape Times, 15.7.1972, p.1; Die Burger, 15.7.1972, p.1.

S.A. Naval Museum: History of the mine countermeasures flotilla 1922-1988 (unpublished manuscript), p.49. 
In 1973 SAS Tafelberg once again acted as guardship during the Cape to Rio yacht race. She left Simon's Town on 8 January 1973, and arrived in Cape Town harbour the next day. The race started on 13 January. Until 15 January, the minesweeper SAS Walvisbaai also took part in guardship duties. On 3 February the Tafelberg rendezvoused with the Brazilian hydrographic survey vessel Sirius, and the two ships sailed together until 15 February, when the Sirius took over all the guardship duties. The Tafelberg sailed to Buenos Aires in Argentina, arriving on 20 February. Several receptions were held. The ship sailed again on 2 March and arrived back in Simon's Town on 14 March 1973. ${ }^{41}$

In that same year, from 29 March to 7 April 1973, SAS President Kruger, SAS President Steyn and SAS Johanna van der Merwe visited Lourenço Marques, the last visit of its kind before Mozambique became independent. ${ }^{42}$ The fact that both Mozambique (on 25 June 1975) and Angola (on 11 November 1975) became independent under pro-communist governments had serious strategic implications for the apartheid regime in South Africa, and also meant that for many years to come, South Africa's grey diplomats would not be welcome in Angolan and Mozambican ports. As a matter of fact, South Africa would henceforth have to face growing international isolation, something that had a very negative impact on naval diplomacy.

\section{GROWING ISOLATION, 1974-1979}

The Namibian War of Independence (1966-1989) in due course spilled over into Angola, and units of the SAN patrolled the Angolan coast. So, for example, SAS President Steyn would have visited the French island Reunion from 24 to 28 November 1975, but was sent to the coast of South-West Africa (Namibia) and Angola instead to assist the South African forces that had invaded Angola ("Operation Savannah"). ${ }^{43}$

With SAS Tafelberg supporting South African warships involved in the Angolan conflict, SAS Protea (Capt. J.H. le Roux) acted as the guardship for the 128 yachts taking part in the 1976 Cape to Rio race. The Protea visited Rio de Janeiro at the end of her guardship duties. ${ }^{44}$ In that same year, a South African warship visited the United States of America for the first time. That country celebrated its 200th year of independence on 4 July 1976, and although the naval relations between the RSA and USA had been at a very low ebb since February 1967 when the aircraft-carrier USS Franklin D. Roosevelt visited Cape Town and black American sailors were not allowed to go ashore because under apartheid

41 Paratus 24(4), April 1973, pp. 32-33, 62; S.A. Naval Museum: Cape to Rio race guardship duties - SAS Tafelberg - report of proceedings; The Argus, 13.1.1973, pp. 1, 11;Die Burger, 13.1.1973, p.1 and 15.1.1973, pp. 1,3 .

42 Du Toit, p. 229.

43 Ibid., pp. 230-231. As far as the SAN's involvement in "Operation Savannah" is concerned, see e.g. F.J. du T. Spies, Operasie Savannah: Angola 1975-1976(Pretoria, 1989), pp. 141-142, 147, 168, 174-176, 297.

44

Du Toit, p. 263; Die Burger, 11.12.1975; The Cape Argus, 10.12.1975, p.6. 
laws they could not be guaranteed equal treatment, a late invitation was eventually sent to the South African Navy to send a warship to the USA to take part in the international naval review to be held in New York harbour. After less than two weeks' notice of the visit, SAS President Kruger left Simon's Town on 3 June 1976 under the command of Capt. P.A. Wijnberg. After visiting Walvis Bay (5-6 June), Abidjan (11-12 June) and Las Palmas (1719 June), "PK" crossed the North Atlantic, arriving at the largest US Naval Base at Norfolk, Virginia, on 29 June. On 1 July the frigate sailed from Norfolk to a point about 180 nautical miles south-east of New York, where the review ships would rendezvous. Fiftythree naval vessels from 22 countries, including the USA, then set sail for New York, passing in a single column under the Verrazano Narrows Bridge on the morning of 3 July, and then heading for their assigned review anchorages from Ellis Island in the south to the Narrows Bridge. "PK" anchored only about $500 \mathrm{~m}$ from the Statue of Liberty. ${ }^{45}$

The next day the international naval review took place, in which sixteen tall ships also took part, after which "PK" weighed anchor and berthed at Pier 40, Lower Manhattan. The Navy's grey diplomat was open to the public on two days and more than 6000 people visited the ship. On 6 July a portion of the crew took part in a ticker-tape parade down Broadway, together with some 2000 other naval personnel from across the globe. The next day SAS President Kruger sailed for Charleston in South Carolina for a three-day visit (9-11 July) before departing for home, arriving back in Simon's Town on 6 August. On the way home "PK" once again visited Las Palmas (22-24 July), and was refuelled at sea on 29 July by SAS Tafelberg. This pioneering and memorable cruise of 16925 nautical miles lasted 64 days. ${ }^{46}$ Exactly twenty years were to pass before the RSA could send another of its grey diplomats, SAS Drakensberg, to the USA in 1996.

In the meantime, the Simon's Town Agreement was abrogated by the British Labour Party government on 16 June 1975, in effect ending the historical close relationship between the Royal Navy and SAN. ${ }^{47}$ Exactly a year later, the Soweto riots broke out, and intensified measures were implemented by the apartheid regime to quell all opposition. This in turn led to the all-embracing mandatory arms embargo imposed against South Africa by the United Nations on 4 November 1977. The SAN was severely hit when the delivery of two Type A69 corvettes and two "Agosta" class submarines was embargoed. However, the Navy did receive three "Minister", now the "Warrior" class fast attack craft (FAC's), also known as strike craft. These three ships - SAS Jan Smuts, SAS P.W. Botha (renamed SAS Shaka in 1997) and SAS Frederic Creswell (renamed SAS Adam Kok in 1997) - arrived in Simon's Town in September 1977, January 1978 and May 1978 respectively. ${ }^{43}$ Flag-showing opportunities were now extremely limited.

Du Toit, p. 232; information supplied by Rear Adm. (rtd) P.A. Wijnberg.

Information supplied by Rear Adm. (rtd) P.A. Wijnberg; Navy News 11, April 1992, p. 27; Du Toit, p. 232.

A. du Plessis, Die maritiem-strategiese betekenis van die Simonstad-vlootbasis (Pretoria, 1979), pp. 26-27.

Du Toit, pp. 176, 298; Henshaw, p. 440; Maritime Expo 97: the official souvenir catalogue, p.16. 
Sometimes showing the flag was of secondary importance during a cruise, but a certain type of cruise could still be utilised for that purpose. A case in point is SAS Protea's cruise to the Antarctic during an international krill research project for the Department of Fisheries in 1978. The Protea sailed from Simon's Town on 31 January 1978 under the command of Capt. C.J.H. Wagenfeld, arrived in Cape Town that same day, and sailed again on 10 February. On board were one German and six South African scientists, as well as a Wasp helicopter (No. 93). The leader of the scientists was Dr D.L. Cram of the Division of Fisheries. Krill's nutritional value can be used in various ways, e.g. freeze it as it is and make it into soups and stews, pulp it and market the oil and protein as paste, or turn it into powder. The scientists also made a survey of birds as part of an international scientific programme (Project Biomass) which studied all the living resources of Antarctica. The Protea became the first unit of the South African Navy to sail around Cape Horn (26 February), and then through the Beagle Channel to Ushuaia in Argentina, the southernmost town in the world, arriving on 27 February to pick up a South African and a German scientist, and leaving again the next day. Subsequently the ship sailed to Deception Island (part of Britain's South Shetland Islands, anchoring off the island, 5-6 March) and Grytviken (22-25 March) in South Georgia (also a British possession), doing research underway, past another British possession, namely the Falkland Islands, and on to Puerto Belgrano in Argentina (staying 5-10 April), and arriving back in Simon's Town on 21 April 1978.49

Political considerations compelled the organizers of the fourth Transatlantic yacht race (1979) to switch the finishing point from Rio de Janeiro in Brazil to Punta del Este in Uruguay. The race started in Table Bay on 13 January 1979, with SAS Fleur as the startship. A total of 36 yachts took part. As was the case during the 1976 race, SAS Protea (under command of Capt. John de Wet and with a total crew of 116) was the guardship, visiting Ilha da Trinidade (a Brazilian island group, 1-9 February), arriving at Punta del Este on 18 February and sailing again the next day to Montevideo in Uruguay (19-22 February) and Buenos Aires in Argentina (22-27 February). Two SAN yachts also took part in the race, namely Voortrekker (skippered by Warrant Officer Mike Avery) and Fair Lady (skippered by C.P.O. Bertie Reid). The Protea arrived back in Simon's Town on 10 March. $^{50}$ This was to be the last opportunity in nearly a decade to show the South African flag abroad during a naval visit.

\section{TOTAL ISOLATION, 1980-1986}

The mandatory arms embargo and running costs forced the SAN to reconsider its role. It was decided to concentrate on defending the RSA's harbours, coastline, and maritime

49 Du Toit, p. 264; Navy News [2], Aug. 1982, p. 14; line-book: SAS Protea; The Argus, 4.2.1978; The Cape Times, 11.2.1978; log-book: SAS Protea.

so Navy News [2], Aug. 1982, p. 14; Du Toit, p. 265; The Cape Times South Atlantic Supplement, 12.1.1979, p.3; log-book: SAS Protea. 
interests, and to abandon the Navy's blue-water role, i.e. the role of a pro-Western guardian of the Cape sea route. The arms embargo led to a spectacular period of growth in South Africa's armaments industry. Thirty small "Namacurra" class harbour protection boats were built locally, as well as another six "Minister" ("Warrior") class FAC's. Four "River" class minehunters were also acquired by the Navy. ${ }^{51} \mathrm{FAC}$ 's and minehunters are traditionally not considered to be ideal grey diplomats, because - relative to vessels like frigates and destroyers - they are "undersized", can therefore send out all the wrong signals, and in any case, simply do not have sufficient space on board to allow many guests to take part in diplomatic or other exchanges. ${ }^{52}$ However, in due course, the SAN did use some of these small vessels as grey diplomats, not only proving that under adverse political and financial circumstances they could in fact be employed successfully on flag showing cruises, but also providing proof of the remarkable skills and seamanship of the Navy's personnel.

In line with the Navy's new role as guardian of the RSA's harbours and coastal waters, the frigate SAS President Steyn was withdrawn from service on 1 August 1980, and she was gradually stripped of all equipment to provide spare parts for the two other frigates. In the early hours of 18 February 1982 tragedy struck the SAN when - during an exercise with other naval units in the South Atlantic, 78 nautical miles south-west of Cape Point the frigate SAS President Kruger (Capt. W.J. de Lange) sank after a cullision with the replenishment vessel SAS Tafelberg (Capt. N.M. Smit). Sixteen members of the "PK's" crew were lost. Although it was at one stage planned to rebuild both SAS President Steyn and SAS President Pretorius, these plans were later shelved. "PS" was sunk as a target on 29 April 1991, and "PP" withdrawn from service on 26 July 1985 and sold for scrap in 1992. With the demise of the Type 12 frigates, the SAN was left without any traditional grey diplomats. In 1985 the Navy, as part of a drastic rationalisation process, decommissioned six "Ton" class mine countermeasures vessels, all five the "Ford" class SDB's, as well as another patrol boat, a search and rescue vessel, and SAS Somerset, the Navy's last boom defence vessel. ${ }^{53}$

On 30 August 1984 the keel of the replenishment ship SAS Drakensberg was laid down at the Bayhead shipyard of Sandock Austral in Durban. This was to be the most ambitious ship-construction project undertaken to date in South Africa. The ship was launched on 24 April 1986, and commissioned into the Navy on 11 November 1987.54 Although it could not have been fully envisaged at that time, the Drakensberg in due course became South Africa's most successful grey diplomat to date. By the time the Drakensberg was commissioned, the SAN found itself in a unique position in that it now had two replenishment vessels - or, combat support ships, as they are also termed - but no major surface combatants to be supported!

\footnotetext{
51 Du Toit, pp. 176, 178, 294-306, 310, 315.

52 Edmonds and Mills, p. 73.

53 Du Toit, pp. 207, 210, 216, 218-219, 234-239.

54 Ibid., pp. 316-317, 320 .
} 


\section{MOVING TOWARD A NEW ERA, 1987-1993}

On 28 November 1987 the "Helderberg", a Boeing 747 of the South African Airways, crashed near Mauritius en route to South Africa from Taiwan. All 160 persons on board died in this tragic event in South African aviation history. The replenishment vessel SAS Tafelberg (Capt. Eric Green) and the strike craft SAS Jim Fouché (renamed SAS Sekhukhune in 1997; Cdr G.N. Engelbrecht) were sent to Mauritius to assist in rescue attempts and in the search for wreckage and the "black box" of the aircraft. The Jim Fouché sailed from Durban and arrived in the search area on 2 December. The Tafelberg left Simon's Town on 1 December, loaded transportable logistic support containers in Durban to assist the strike craft, and arrived in Port Louis, Mauritius, on Wednesday 9 December. On board was also a Puma helicopter. Debris and wreckage were collected by the Tafelberg's launches. The Jim Fouché returned to Durban before the Tafelberg. The Tafelberg left Port Louis for the last time on 23 December, sailed to the Comore Islands to pick up a Court Line Sikorsky helicopter (to replace the Tafelberg's Puma), but when it transpired that the helicopter was no longer available, the Tafelberg did not enter a port, arrived in Durban on 2 January 1988, and was back in Simon's Town on 5 January. ${ }^{55}$ Although this was primarily a rescue and assistance operation, the Jim Fouché and Tafelberg became the first SAN vessels in many years to show the South African flag abroad.

Even before the end of the Namibian War of Independence (1966-1989) and the dramatic political changes that took place in South Africa (heralded by Pres. F.W. de Klerk's watershed speech in parliament on 3 February 1990, unbanning several political organisations like the ANC and PAC, and paving the way for multi-party negotiations to start on the political future of the country), two South African naval vessels broke the international. isolation by sailing to Chile in South America to offload Armscor equipment to be exhibited at the FIDA ' 88 International Air Show, held at the El Belloto Air Force Base. SAS Drakensberg (under the command of Capt. N.M. Smit) - with a Puma and a Wasp helicopter on board - and the strike craft SAS Frans Erasmus (renamed SAS Isaac Dyobha in 1997; Cdr T.M. Day), left Simon's Town on 15 February $1988 .{ }^{56}$ The latter craft was definitely not the type of grey diplomat usually deployed during transoceanic flag-showing visits.

The ships sailed via the Magellan Strait to Valparaiso, Chile's main harbour and naval base, arriving on 2 March. They were greeted by a gun salute, traditional local dancers on the quayside, and by Vice-Adm. G. Syndercombe, Chief of the South African Navy. He visited Chile to meet the chief of the Chilean Navy and other senior officers, to investigate the possibilities of further strengthening the already good ties between the two navies, and of even closer co-operation. The equipment for the exhibition was offloaded, the centre-

55 Ibid., p. 243; Navy News 11, May 1992, pp. 5-6; information supplied by Cdre S.K. Stead.

56

Du Toit, p. 320. 
piece being a G6 self-propelled gun/howitzer, the pride of Armscor and the South African Defence Force at that stage. On 10 March the two warships sailed to the naval base at Talcahuano, south of Valparaiso, where they stayed until 14 March, and subsequently sailed to Puerto Montt, where they stayed from 16 until 18 March. While SAS Drakensberg returned to Valparaiso (arriving on $20 \mathrm{March}$ ) to pick up all the equipment, the FAC sailed to Punta Arenas, where the Drakensberg teamed up with her on 3 April before the duo set sail for Simon's Town (via Cape Horn) on 4 April. After a very successful flag-showing cruise the task force arrived back in Simon's Town on 16 April. ${ }^{57}$

In the course of 1988, SAS Drakensberg also paid two visits to Beira in Mozambique; the first time since 1957 that the SAN sent a ship to that port. The purpose of the Drakensberg's visits was to supply the Mozambican government with non-combat military equipment and vehicles to help them in their efforts to protect the strategically important Cabora Bassa power line which carries power to South Africa, but was threatened by the RENAMO movement. The Drakensberg sailed from Simon's Town on 21 November 1988, arrived in Durban two days later, loaded the equipment, and sailed for Beira on 26 November, where the ship arrived early on 28 November. After offloading the equipment, the Drakensberg sailed on 29 November, arrived in Durban on 1 December, took on board another cargo of equipment, and sailed once again for Beira on 3 December. The ship berthed in Beira harbour shortly after midnight on 6 December, offloaded the equipment, and sailed again that same afternoon. The ship arrived in Durban on 8 December and sailed for Simon's Town that same day, where she arrived on 10 December $1988 .^{58}$

Two years later the Navy embarked on an even more ambitious flag-showing expedition, when SAS Drakensberg and strike craft SAS Jan Smuts and SAS Hendrik Mentz were sent all the way to the Republic of China (ROC; Taiwan), another country with whom the RSA had retained strong diplomatic and military ties throughout the apartheid years. In 1981, 1985 and 1989 (and later also in 1992 and 1996) Taiwanese naval task forces visited South Africa on training cruises and held exercises with units of the South African Navy. ${ }^{59}$ Now, for the first time, South African warships would visit the ROC; as a matter of fact it would be the first time since shortly after the end of the Second World War that South African warships would be in the waters of the Far East. ${ }^{60}$

The Drakensberg (under the command of Capt. Fred Marais) left Simon's Town on 8 May 1990, arriving in Durban on 10 May. There the ship teamed up with the locally-based

57 Ibid.; Navy News 7, June 1988, pp. 2, 7-10, 16 and 11, April 1992, p. 27.

58 C.J. Nöthling, Geskiedenis van die Suid-Afrikaanse Weermag 2 (Silverton, 1996), p.35; information supplied by Lt A.P. Putter and Sub-Lt D.J. Olivier, SAS Drakensberg.

59. Paratus 32(6), June 1981, p. 16, 36(9), Sept. 1985, pp. 20-21 and 43(7), July 1992, p. 8; Navy News 8, July 1989, p. 11 and 15, June-July 1996, p. 13.

60 As far as the role of the South African warships HMSAS Barbrake and HMSAS Natal, and South Africanmanned warships HMS Salvestor and HMS Teviot in the Far East during the closing days of World War II and the following months is concerned, see e.g. A. Wessels, "South Africa and the war against Japan 1941-1945", Military History Journal 10(3), June 1996, pp. 88-89. 
SAS Jan Smuts (Cdr Dennis Forrest) and SAS Hendrik Mentz (renamed SAS Galeshewe in 1997; Cdr Roger Steven-Jennings), and sailed for Taiwan the next day (11 May). As the task force left Durban harbour, the Chief of the South African Navy, Vice-Adm. "Dries" Putter, took the salute from North Pier. On board the Drakensberg was a Puma helicopter, and instead of the usual crew of 106 , no fewer than 276, including at least 96 members of a naval display team. With the crews of the two FAC's included, nearly 400 personnel sailed for Taiwan. The task force was under the overall command of Rear-Adm. L.J. Woodburne, the designated Chief of the Navy. He would only accompany the ships on the outward journey, as he had to return to in South Africa by 22 June to relieve Vice-Adm. Putter. The purpose of "Operation Nexus" was to foster even better relations with Taiwan, to exercise the Navy's capability to undertake a long voyage at sea, and to train personnel. ${ }^{61}$

On passage to Taiwan the task force sailed via the Mozambique Channel, north-east past Madagascar, and crossed the Indian Ocean. The vessels then sailed through the Strait of Malacca between Sumatra and the Malaysian Peninsula, and across the South China Sea to Keelung in northern Taiwan, where they arrived on 31 May 1990. There they were welcomed at the quayside by naval personnel, schoolchildren and dancers, and were given VIP treatment throughout their stay. They celebrated what was then known as Republic Day (31 May), and on 4 June the task force set sail for Kaohsiung, exercising with units of the ROC Navy underway, and arriving on 5 June. During the visit to Taiwan there were several functions and sightseeing tours, while the senior officers embarked on several official visits. A rugby match was even played between South African and ROC navy teams - and the South Africans were given a sound drubbing by their Taiwanese hosts! From Kaohsiung the task force left on 8 June to return home, sailing via the Sundra Strait between Sumatra and Java in Indonesia and past the volcanic island of Krakatoa which had erupted on 27 August 1883, killing more than 36000 people, and creating a tidal wave that even affected the English Channel, albeit two days later! On 13 June the Drakensberg 's helicopter reconnoitred Krakatoa from the air. During the whole voyage, the task force had fine weather on all but three days, when they had to sail through a tropical cyclone, Ikonjo, and that was on the outward journey. A day before arriving in Durban, the task force rendezvoused with the strike craft P1569 (christened SAS Magnus Malan in 1992, and renamed SAS Makhanda in 1997). The task force arrived safely back in Durban on 25 June, having been away for 45 days since they left Durban, and having sailed 13944 nautical miles. On 28 June SAS Drakensberg arrived back in Simon's Town. ${ }^{62}$

Shortly before the Drakensberg task force left for the Far East, another of the Navy's grey (albeit in this case white!) diplomats, namely SAS Protea, was sent to Europe on

61 Du Toit, p. 320; Paratus 41(6), June 1990, p. 32; The Natal Mercury, 12.5.1990, p. 4 and 26.6.1990, p. 2; Navy News 9, Aug. 1990, p. 10; Nöthling, p. 56.

62 Navy News 9, Aug. 1990, pp. 2, 10, 11, 15, 16, 20; Paratus 41(9), Sept. 1990, p. 26; Du Toit, pp. 307, 320; Nöthling, p. 56; The Natal Mercury, 26.6.1990, p. 2. 
another flag-showing visit. She was the last South African naval vessel to visit a European port (Lisbon, in 1972 on her maiden voyage), and now she would visit Lisbon again, with two of her original crew members once again on board. Since SAS President Kruger had visited the USA in 1976, the Protea would now be the first SAN vessel to once again visit a NATO port. The ship's primary purpose during "Operation Diaz", as the trip was called, was to act as guardship for the yachts that took part in the second Portnet Dias race from Cape Town to Lisbon. The voyage was also used for the training of junior naval members. The ship sailed from Simon's Town on 18 April 1990 under the command of Cdr Bernhard Teuteberg. On passage to Lisbon the Protea visited Portugal's Azore Islands, berthing at Porta Delgada (10-14 May). From there the ship sailed to Lisbon, arriving on 17 May. Three yachts of the South African Navy took part in and completed the race, with Voortrekker II taking line honours; the other two being Voortrekker I and Shelly Anne. On passage back to South Africa, Cdr Teuteberg became ill and the ship was forced to make an unscheduled stop in Abidjan. The last time a South African warship visited that port in Côte d'Ivoire, was in 1976, when SAS President Kruger called on passage to the USA. Cdr Teuteberg was taken ashore and airlifted home by a plane of the South African Air Force. While in port, the chief of Côte d'Ivoire's navy welcomed the crew. On 16 June 1990 the Protea was back in Simon's Town, after a very successful cruise. ${ }^{63}$

Even a trip that is in the first place undertaken as a relief cruise, can be used for diplomatic purposes. "Operation Pullen" is a case in point. On 22 August 1990 the "River" class minehunters SAS Umhloti (Cdr George Basson) and SAS Umzimkulu (Cdr Richard Loydell) left Simon's Town, followed five days later by the faster SAS Drakensberg (Capt. Fred Marais). The task force was under the overall command of Capt. Errol Massey-Hicks. On 31 August the three vessels rendezvoused off the coast of Zaire (since 1997 known as the Democratic Republic of the Congo) and then sailed up the Zaire (Congo) River to the port of Banana, arriving on 1 September. In 1959 SAS Good Hope and SAS Vrystaat had been the last South African warships to visit the country, then still a Belgian colony. At Banana and later at Boma (7-10 September) crew members cleared the berths and did a great variety of repair work. The Drakensberg and the minehunters then sailed further upriver to Matadi, where they stayed from 11 to 17 September. While in Zaire, the South African sailors took part in several sports meetings with their hosts. The Zairean minister of Defence, Adm. Mavua was entertained on board the Drakensberg, and Capt. MasseyHicks was invited by the minister to attend a passing-out parade at Kinshasa of officers who had completed a combined staff course. Shortly before the South Africans left Zaire, the chief of the Zairean navy, Rear-Adm. Liwanga Mata-Nyamunyobo, inspected the work that had been done. The task force sailed from Banana on 20 September, and arrived back

63 Line-book: SAS Protea; Navy News 9, July 1990,pp. 12, 15, 17 and 11, April 1992, p. 27; SABC-TV news bulletin, 20h00, 18.5.1990; Du Toit, p. 265; The Natal Mercury, 5.6.1990, p. 6; Public Relations Directorate, S.A. Naval Headquarters, Pretoria: S.A. Navy deployments Jan. 1990-Jun. 1997, p.1. 
in Simon's Town on 25 September 1990. This successful operation was the beginning of closer co-operation between the South African Defence Force and other African countries. $^{64}$

Nearly twenty years after she had last shown the South African flag abroad (in 1973, in Argentina) the Navy's grand old lady, SAS Tafelberg (under the command of Capt. Bob Harrison) went on her longest ever cruise, namely a training cruise ("Operation Gypsy") that took her right around South America. The voyage had a fourfold mission, namely to train midshipmen, demonstrate the breakdown of diplomatic isolation, strengthen bonds with other countries, and to transport the naval yacht Voortrekker to the Copa 1000 Millas Yacht Race. "Mamma Tafies" left Cape Town on 7 January 1991 with a Puma helicopter on board, sailed across the Atlantic and via the Strait of Magellan to Valparaiso in Chile, arriving on 25 January. She offloaded the Navy's entry in the Copa Millas 1000 nautical miles yacht race (1-15 February) and stayed in port for two weeks, before sailing on 3 February to Talcahuano (staying 4-8 February), then to Puerto Montt (9-13 February), and back again to Valparaiso (15-18 February) to pick up the Voortrekker II - which had in fact won the yacht race. After also taking on board the Ecuadorian Navy yacht Alcane, the Tafelberg sailed north on 18 February to Guayaquil in Ecuador, arriving on 24 February the first ever visit to Ecuador by a South African warship. The intended call to Peru was cancelled due to a cholera epidemic in that country. Once again sailing northwards (on 27 February), the Tafelberg became the first (and so far only) South African warship to sail through the Panama Canal (2 March 1991). The ship then made a courtesy call lasting three days at the Colombian port of Cartagena (4-6 March). As usual, there were several functions. From there the ship was supposed to sail all the way back to Simon's Town without any stops, but technical problems forced the captain to call at Recife in Brazil (1718 March). The planned visit to Buenos Aires in Argentina was called off due to the sensitivity of such a call before a planned visit by Mr Nelson Mandela, then still taking part in negotiations with the South African government. On 31 March 1991 "Mamma Tafies" was safely back in Simon's Town. Although the cruise was primarily aimed at the training of midshipmen and junior officers as part of their career development, the voyage had also been a diplomatic success. ${ }^{65}$

So, even before the political parties in the RSA sat down for serious negotiations, and while the country was still not officially welcomed back by the international community, the country's Navy was already restoring military and diplomatic ties, and, in some cases,

64 SABC-TV news bulletins, 20h00, 7.9.1990 and 26.9.1990; Du Toit, pp. 314, 321; Navy News 9, Jan.-Feb. 1991, pp. 12-13; Paratus 41(10), Oct. 1990, pp. 8-9.

65 Du Toit, p. 244; The Natal Mercury, 10.1.1991, p. 4; Paratus 42(2), Feb. 1991, p. 5; G. Wardley, “Operation Gypsy - SAS Tafelberg's South American adventure”, Unisa Latin American Report 7(2), 1991, p. 89; Navy News 10, April-May 1991, pp. 12-16; Public Relations Directorate, S.A. Naval Headquarters, Pretoria: S.A. Navy deployments Jan. 1990-Jun. 1997, p.3. 
even forging new ones. After all, the South African Navy emerged from the apartheid years with the least tarnished reputation of all the armed forces.

While on patrol along South Africa's west coast on 22 March 1991, the strike craft SAS Oswald Pirow (renamed SAS René Sethren in 1997; under the command of Cdr A. Jacobson) and minehunter SAS Umkomaas (Cdr R.R. Goveia) were asked to assist Namibia in apprehending three Spanish trawlers fishing illegally in Namibian waters, but close to South African waters, and heading towards the South African Exclusive Economic Zone. In what was known as "Operation Marlin Spike", the South African naval vessels intercepted the Spanish trawlers Cabu Primero, Altassa Quatro and Cotoredondo Quatro, and escorted them back to Namibian waters, where they were handed over to the crew of the Namibian fisheries inspection vessel Oryx. The Namibian, South African and Spanish vessels then sailed to Lüderitz, where the Spanish captains were arrested for illegally fishing in Namibian waters. The South African naval visit to Lüderitz on $23 \mathrm{March}$ 1991 was the first by the S.A. Navy to a Namibian port since that country became independent on 21 March 1990. ${ }^{66}$

SAS Drakensberg's first flag-showing cruise of 1991 was primarily an astro-navigation training cruise for fourteen students from the Military Academy at Saldanha Bay. "Operation Bob Cat" lasted from 20 June to 4 July 1991 and took the ship, under the command of Capt. Fred Marais, to the island of St Helena, a British possession. Capt. Marais made a goodwill visit to the British governor, Mr Allan Hoole, who in turn visited the Drakensberg. Crew members cleaned and restored the graves of Boer prisoners of war who had died on the island during the Anglo-Boer War (1899-1902), a wreath-laying ceremony took place, and soccer and cricket were played against the local teams. ${ }^{67}$

"Operation Chant" was a much larger operation and took SAS Drakensberg (once more under command of Capt. Fred Marais) to several ports never before visited by a South African warship. The main purpose of the trip was to deliver about 785 tons of relief material (food, clothing, building material and medicines worth about R3 million) that was donated by the Islamic Relief Agency (ISRA) to three groups of victims: people in floodravaged Bangladesh, the persecuted Kurds in northern Iraq who had fled to Turkey, and the people in drought-stricken Sudan. In Cape Town, 35 tons of goods were loaded on board the ship, and in Durban about 750 tons. The Drakensberg left Simon's Town on 15 July for Cape Town, and left the latter on 17 July 1991. From Durban she sailed on 21 July 1991 to Chittagong in Bangladesh (arriving on 2 August) where most of the supplies (about 630 tons) were offloaded. The Drakensberg left Chittagong on 4 August and then became the first South African warship since the Second World War to sail through the Suez Canal (16 August). From there the ship sailed to Mersin in Turkey where the relief material for

66 Public Relations Directorate, S.A. Naval Headquarters, Pretoria: S.A. Navy deployments Jan. 1990-Jun. 1997, p. 4 ; line-book: SAS Oswald Pirow (SAS René Sethren), p.89.

67 Navy News 10, Aug.-Sept. 1991, p. 9; Du Toit, p. 321; Nöthling, p. 57. 
the Kurds was offloaded, staying in port from 18 to 21 August. While in port, Rear-Adm. Tanzel Dincer (commander of NATO's southern Mediterranean fleet) and Muharrem Goktayolgu (governor of the southern Turkish province of Ical) paid at least three courtesy visits to Capt. Marais and his officers. From there the Drakensberg sailed back through the Suez Canal (22 August) to Port Sudan, but there had been an attempted coup in the Sudan, and the ship did not enter the harbour. The last stop was Nacala in Mozambique, where the material that was originally destined for the Sudan (about 120 tons) was offloaded on 3 September. On 8 September 1991 the ship was back in Simon's Town, having sailed a total of approximately 15800 nautical miles in 55 days ${ }^{68}$ Although many frustrations were experienced, the Drakensberg had brought relief to many victims of natural disasters and political persecution, and - as a bonus - had shown the South African flag in ports never before visited by a South African warship. It had in fact been a breakthrough diplomatic mission.

With parties in the RSA moving closer to a political settlement, more doors opened up for the country - and for its Navy. When Pres. F.W. de Klerk visited Kenya in June 1992, the Durban-based strike craft SAS Frans Erasmus (renamed SAS Isaac Dyobha in 1997; under the command of Cdr A. van der Westhuyzen) and SAS Magnus Malan (renamed SAS Makhanda in 1997; under the command of Cdr Roger Steven-Jennings) were sent to Mombasa on a goodwill visit, arriving on 18 June. Cdr B.R. Donkin, commander of 1 Strike Craft Squadron in Durban, was the overall commander of the "task force", and he made official calls to the deputy commander-in-chief of the Kenyan Navy, the mayor of Mombasa, and the provincial commissioner. The two FAC's arrived back in Durban on 24 June, after conducting a replenishment at sea (RAS) some 30 nautical miles west of Grande Comore with the hydrographic survey ship SAS Protea on 21 June, the latter on its way back to South Africa after visiting several European countries. ${ }^{69}$

When the Navy was invited to send a ship to Monaco to coincide with the 14th conference of the International Hydrographic Organisation which is held every five years, this was jumped at as a golden opportunity to show the South African flag in Mediterranean ports. SAS Protea (under the command of Capt. B.D. Law) left Simon's Town on 9 April 1992 ("Operation Hyson") and sailed up the west coast of Africa and through the Straits of Gibraltar (without calling at any ports), arriving in the harbour of Monte Carlo (in the principality of Monaco) on 2 May. A number of official functions were hosted. From there the Protea sailed on 8 May to Genoa in Italy, arriving on 9 May, the first time since World War II that a South African warship visited that port. The next day the ship was open to the

68 Public Relations Directorate, S.A. Naval Headquarters, Pretoria: S.A. Navy deployments Jan. 1990-Jun. 1997, p.6; Sunday Tribune, 25.8.1991, p. 19 and 8.9.1991, p. 17; The Natal Mercury, 7.8.1991, p. 6 and 7.9.1991, p. 1; Du Toit, p. 321; Navy News 10, Nov.-Dec. 1991, pp. 8-11 and 11, June 1992, pp. 8-9, 14; The Daily News, 6.8.1991, p.4, 7.8.1991, p.6 and 7.9.1991, p.5.

69 The Natal Mercury, 19.6.1992, p. 1 and 25.6.1992, p. 12; Afrikaans Stereo (Radio), news bulletin, 23h00, 18.6.1992. 
public. The ship left on 11 May, sailed through the Dardanelles to Istanbul, anchoring for eleven days off the Dolmabahce Palace (18-29 May), and then through the Bosporus to Constanta in Romania, becoming the first South African warship to visit that country ( 30 May-1 June); as a matter of fact, it was the first time a South African warship had entered the Black Sea. The Protea then sailed back through the Bosporus and Dardanelles and via the Suez Canal (5 June) to Simon's Town, arriving back on 30 June. Because of engine problems the Protea did not visit Mombasa. In the Mozambique Channel the Protea airlifted an ill seaman from the tanker Chevron Nagasaki on 23 April. The RAS with two strike craft just west of the Comores has already been referred to. The "White Lady" covered 14435 nautical miles during her 82-day cruise. ${ }^{70}$

A relief operation to Mombasa in Kenya afforded the Tafelberg one last opportunity to act as a grey diplomat. The South African branch of the African Muslim Agency (AMA) asked the South African Department of Foreign Affairs for assistance to transport approximately 670 tons of food (worth about R2,6 million) to Kenya for distribution amongst the Somalian refugees in northern Kenya. "Mamma Tafies" sailed from Simon's Town on 16 September ("Operation Flush/Big Tree") under command of Capt. J.A.J.B. (Jan) Vorster, loaded the relief material in Durban and left on 22 September. On board were also a Puma helicopter, 60 midshipmen from the South African Naval College in Gordon's Bay, nine journalists, eight women, two officers of the Department of Foreign Affairs, and four Muslim theologians from the AMA. The ship arrived in Mombasa on 27 September, offloaded the food, and sailed again on 30 September. Although primarily a mission of assistance, several diplomatic visits were undertaken in Mombasa, and ties between the South African and Kenyan navies were strengthened. In the Mozambique Channel three strike craft joined the ship and conducted a number of exercises, including RAS. SAS Tafelberg was back in Simon's Town on 14 October. ${ }^{71}$

Sadly, this was the Tafelberg 's last cruise. After nearly 26 years' service in the SAN, the maintenance of the 35-year old ship had become uneconomical, and the "grand old lady" was withdrawn from service on 17 March 1993. In her place, the former Ukrainian-built Arctic supply vessel Juvent (completed in 1992), was commissioned into the SAN on 8 June 1993 as the combat support ship SAS Quteniqua, with Capt. Jan Vorster, the Tafelberg's last commanding officer, as the first captain of the Navy's latest acquisition. ${ }^{72}$ So, "Mamma Tafies" was replaced by a ship that in due course became an equally successful although some would add equally peculiar or ugly-looking, grey diplomat.

70 Public Relations Directorate, S.A. Naval Headquarters, Pretoria: S.A. Navy deployments Jan. 1990-Jun. 1997 p.9; Paratus 43(7), July 1992, p. 16; Du Toit, p. 265; The Natal Mercury, 24.6.1992, p. 1; Navy News 11, Aug. 1992, pp. 9-10.

7 Nöthling, p. 57; Navy News 11, Nov.-Dec. 1992, p. 2 and 12, Jan-Feb. 1993, pp. 10-11; The Natal Mercury, 5.10.1992, p.4; Paratus 43(11), Nov. 1992, pp. 18-19; Die Burger, 16.9.1992, 2.10.1992 and 8.10.1992, p. 17; The Daily News, 23.9.1992; Sunday Tribune, 11.10.1992, pp. 8-9.

72 Navy News 12, April 1993, pp. 1C-11 and 12, July 1993, pp. 10-13. 
At the beginning of 1993 the South African Navy deployed its relatively strongest task force on a foreign cruise. The purpose of the cruise was to escort the yachts that took part in the Cape to Rio race, take part in exercises ("Atlasur") with South American navies, project the operational image and capability of the Navy, strengthen bonds of friendship, test the Navy's ability to support a large task force for an extended period, and to extend the diplomatic initiatives in South America. The voyage as such was known as "Operation Parka". On 9 January, i.e. the day after the Cape to Rio race started, the submarine SAS Maria van Riebeeck (under command of Cdr A.J.C. Reed) and combat support ship SAS Drakensberg (Capt. P.C. Potgieter) sailed for South America, the latter vessel acting as guardship for the yachts. On 19 January the strike craft SAS Magnus Malan (renamed SAS Makhanda in 1997; under the command of Cdr Roger Steven-Jennings) and SAS Hendrik Mentz (renamed SAS Galeshewe in 1997; under the command of Cdr A.S. ClaydonFink) left their base in Durban, teamed up with the strike craft SAS P.W. Botha (renamed SAS Shaka in 1997 and based in Simon's Town, under the command of Cdr A.G. Green) three days later, and also headed across the Atlantic. All the naval units rendezvoused on 29 January, but the Drakensberg then continued alone to Rio de Janeiro to complete her guardship duties and for a four-day visit (5-9 February), while the other units sailed to Montevideo in Uruguay. The South African Navy's yacht Broomstick (lent to the Navy by owner Michael Kast, skippered by Cdr Hanno Teuteberg) took line honours in the race. The Drakensberg then joined the other SAN ships in Montevideo (13 February), and the whole task force sailed on 16 February to Buenos Aires in Argentina (arriving on 17 February), conducting exercises on passage with units of the Argentinian Navy, namely the submarine Santa Cruz, destroyer Sarandi, corvette Parker and corvette Guerico. The latter vessel was one of the two Type A69 corvettes built for the South African Navy (she would have been named SAS Transvaal), but as a result of the 1977 United Nations arms embargo, the sale was cancelled and the ships sold to Argentina in 1978. The earlier scheduled exercises between the SAN vessels and units of the Uruguayan Navy were cancelled due to heavy seas and unseasonal inclement weather. From Buenos Aires the SAN ships sailed to the Argentinian naval base at Mar del Plata on 21 February (arriving on 25 February), once again exercising on passage, and left on 1 March for the Transatlantic crossing back to South Africa. The surface ships arrived back in Simon's Town on 14 March 1991; the submarine on 21 March. ${ }^{73}$ This deployment of warships and personnel across the Atlantic was a good test for the South African Navy's capabilities and helped the Navy to maintain its edge in its maritime defence role.

In March 1993 SAS Protea did survey work along the northern coast of KwazuluNatal and southern Mozambique. The ship left Simon's Town on 1 March, arrived in

73 The Natal Mercury, 19.1.1993, p. 7; Paratus 44(2), Feb. 1993, p. 13 and 44(6), June 1993, p. 20; line-book: SAS Magnus Malan (SAS Makhanda); Daily News, 25.1.1993, p. 1 and 26.1.1993, p.19; SAS Scorpion: Unit press-cutting book [9.1.1993-28.5.1996]. 
Durban on 4 March, sailed two days later after repairs to the propellor system was done and anchored in Maputo Bay on Sunday 7 March to pick up six Mozambican surveyors. They were flown to the Protea by her Alouette III helicopter in four round trips. After completion of the survey work, the ship once again visited Maputo (19-21 March), and several dignitaries visited the ship. The Protea was back in Simon's Town on 30 March. $^{74}$

On 6 May 1993 SAS Drakensberg (with a Puma helicopter on board) left Simon's Town under the command of Capt. P.C. Potgieter on a tailor-made flag-showing cruise ("Operation Ness") - and in that sense the most important of its kind for that year. The primary purpose of the trip was to participate in the 50th anniversary of the Battle of the Atlantic. On 9 May, in the Midatlantic, the ship suffered problems with the port main engine's clutch assembly. A South African Air Force Lockheed Hercules C-130 was sent out, it rendezvoused with the ship, and in one air-drop dropped numerous spares by parachute. The spares were picked up by one of the ship's Delta craft, and the necessary repairs done at sea. On 20 May the Canary Islands were reached, and on 22 May the Drakensberg arrived in Pembroke, Wales. Sailing again on 24 May, Anglesey was reached the following day. On 26 May the Fleet Review commemorating the Battle of the Atlantic took place in gale-force winds. At least 26 warships from at least sixteen nations took part. The next day SAS Drakensberg berthed in Liverpool next to the Gremyashchy, a Russian "Sovremenny" class destroyer, in the light of the Cold War - and South Africa's international isolation - something unthinkable a few years earlier. ${ }^{75}$

The fact that the British government had invited the South African Navy to send a ship to take part in the commemoration caused some controversy, because by 1993 the United Nations military sanctions against South Africa had not yet been lifted; as a matter of fact the British government had initially declined to invite the South African Air Force (SAAF) to take part in the 1993 International Air Tattoo at RAF Fairford. However, because of the SAN's participation in the Fleet Review, the ban on the SAAF was eventually lifted, but the SAAF was unable to send an aircraft. ${ }^{76}$

The Chief of the South African Navy, Vice-Adm. Robert Simpson-Anderson, also attended the Battle of the Atlantic celebrations, and on 27 May, on board SAS Drakensberg, presented His Royal Highness The Prince Philip Duke of Edinburgh, with the main ship's badge of the destroyer HMS Whelp, later the (HM)SAS Simon van der Stel in which the Prince served during World War II. On 28 May Vice-Adm. and Mrs Simpson-Anderson and Capt. and Mrs Potgieter attended a function hosted by Her Majesty Queen Elizabeth

74 Line-book: SAS Protea; log-book: SAS Protea; Die Volksblad, 19.3.1993, p. 9; Navy News 12, May 1993, p. 16; Afrikaans Stereo (Radio), "Monitor", 1.4.1993.

75 Paratus 44(6), June 1993, p. 15; Navy News 12, Aug. 1993, pp. 9, 14; The Natal Mercury, 26.5.1993, p. 2 and 27.5.1993, p. 5; Sunday Tribune, 27.5.1993; Daily News, 27.5.1993; information supplied by Sub-Lt D.J. Olivier,
SAS Drakensberg.

76 The Natal Mercury, 25.5.1993, p. 5; Navy News 12, Aug. 1993, pp. 8-11, 15; Natal Witness, 22.6.1993. 
II on board the Royal Yacht HMY Britannia, and on that same day members of the Drakensberg's crew took part in a march through the streets of Liverpool. On 31 May the ship sailed home, arriving at Casablanca in Morocco on 5 June. From there the cruise was continued on 8 June to Abidjan in the Côte d'Ivoire (staying from 14-16 June) and Libreville in Gabon (18-20 June). After 51 days away from home, SAS Drakensberg arrived back in Simon's Town on 26 June. ${ }^{77}$ In more than one way, the Drakensberg's 1993 flag-showing cruise to Europe was a turning-point in the Navy's post-1990 history: from now on, the doors (ports!) were open to South Africa's warships, even before the RSA had held its first truly democratic elections.

In the meantime SAS Outeniqua, under command of Capt. Jan Vorster, left on her first flag-showing cruise, "Operation Gunny". From Simon's Town (18 June 1993), the Outeniqua sailed to Durban, leaving that port again on 21 June. The ship arrived in Majunga, Madagascar, on 25 June, a visit that coincided with that country's national day celebrations on 26 June. Crew members took part in a march-past and in sporting competitions against local teams. After offloading medical supplies (a gift to the people of Madagascar, by the good offices of South Africa's Department of Foreign Affairs), the Outeniqua left on 27 June, arriving in Moroni, Grande Comore, on 28 June. From there the ship sailed on 29 June to Port Victoria in the Seychelles (staying from 2-5 July), arriving back in Durban on 10 July, departing on 12 July, and arriving in Simon's Town on 15 July, having sailed 6 115 nautical miles. ${ }^{78}$

Shortly afterwards, SAS Outeniqua left on another cruise, a relief operation ("Operation Seilskoen"), but also an operation with flag-showing possibilities. The main objective of the cruise was to deliver a 126-bed mobile hospital (consisting of 38 containers, plus an ambulance and a bus), as well as other relief supplies to Bosnia-Herzegovina. The R6 million hospital and supplies were donated by the Waqfu'l-Waqifin (Gift of the Givers) Foundation, a Muslim charitable relief organisation, while the consignment of agricultural implements that was to be discharged at Mombasa in Kenya, was donated by the Save Sudan Fund, a South African Christian relief fund. Also included in the cargo were medical supplies donated by the Department of Foreign Affairs for the treatment of Bosnian war refugees. The driving force behind the financing and building of the 126-bed mobile hospital, was Dr Imtiaz Sooliman. ${ }^{79}$

The Outeniqua left Simon's Town under the command of Capt. Jan Vorster on 11 August 1993, arrived in Durban on 13 August, and loaded the equipment and other relief material. Departing from Durban on 15 August, the ship sailed via Mombasa (20-22 Au-

77 The Natal Mercury, 25.5.1993, p. 5; Navy News 12, Aug. 1993, pp. 8-11, 15; Natal Witness, 22.6.1993.

78 Paratus 44(8), Aug. 1993, p. 32 and 44(9), Sept. 1993, pp. 26-28; Tempo, 25.6.1993, p.5; information supplied by Capt. E.H. Lochner, SAS Outeniqua.

79 South African Shipping News and Fishing Industry Review 48(4), July-Aug. 1993, p. 2; Paratus 44 (12), Dec. 1993, p. 37; K. McGregor, "The doctor who never stops giving", Reader's Digest 148(889), May 1996, pp. 25 , 29. 
gust) and the Suez Canal to Trieste in Italy (7 September) and offloaded the containerised hospital and other stores the next day. The ship sailed from Trieste on 9 September to Istanbul in Turkey (staying there from 13-15 September) and Odessa (16-18 September) in the Ukraine; i.e. the country in which the Outeniqua was originally built in 1992. From there the ship sailed to Constanta in Romania (19-21 September), Burgas (21-23 September) in Bulgaria, and back to Istanbul, where a Mfezi military ambulance was shown to delegates attending an international medical conference in that city. Then it was on to Haifa (27-29 September) in Israel. From there the ship sailed via the Straits of Gibraltar and Walvis Bay (17-19 October) to Simon's Town, arriving back on 22 October 1993. The ship had sailed approximately 28800 nautical miles and had been away for 72 days. ${ }^{80}$

\section{SHOWING THE FLAG OF THE NEW SOUTH AFRICA SINCE 1994}

In the last week of April 1994 the first ever truly democratic elections were held in South Africa, and on 10 May Mr Nelson Mandela was inaugurated as the country's first democratically elected president. On 18 May 1994 SAS Drakensberg (under command of Capt. Preston Barnard) left Simon's Town (with a Puma helicopter on board) on a goodwill and operational cruise ("Operation Narsau") to strengthen the international military image of South Africa by participating in various military and other commemorations and exercises, thereby enabling the Navy to assess its capabilities at first hand (which will be invaluable in future planning) and enhancing its operational status - and, of course, to show the new South African flag in as many ports as possible. For the first time in the history of the Navy, two women (Swans) accompanied a ship on a long overseas mission, acting as public relations officers. ${ }^{81}$

The Drakensberg's first port of call was Lisbon in Portugal (2-5 June), where on 5 June 1994 the ship - together with some 27 warships from fourteen other countries - took part in celebrations in honour of the 600th anniversary of the birth of Prince Henry the Navigator. These included a naval review on the River Tagus on 5 June (with Portugal's Pres. Mario Suares taking the salute), a parade at the Monument to the Discoveries at Belem, and a wreath-laying ceremony at the same Monument (in which Capt. Barnard took part). It will be remembered that in 1960 the frigate SAS Vrystaat represented South Africa when the 500th anniversary of the Navigator's death was commemorated. From Lisbon the Drakensberg sailed to the British naval base at Rosyth in Scotland, and subsequently took part in Joint Maritime Course (JMC) 942, a ten-day exercise held in the

80 Paratus 44(11), Nov. 1993, pp. 18-20 and 44(12), Dec. 1993, pp. 37-38; Navy News 13, Jan.-Feb. 1994, p. 10; information supplied by Capt. E.H. Lochner, SAS Outeniqua.

${ }_{81}$ Navy News 13, Oct. 1994, p. 12; Salut 1(2), June 1994, pp. 50-51; Ad Astra 15(10); Oct. 1994, pp. 18-19. 
Outer Hebrides region north of Scotland, with at least ten other surface warships, five submarines and aircraft and helicopters from seven countries. ${ }^{82}$

On 28 June the Drakensberg departed for Copenhagen in Denmark (30 June-2 July), becoming the first South African warship to visit that country, and then sailed to Rotterdam in the Netherlands, staying in port from 4 to 6 July. The last time a South African Navy ship had visited that country, was in 1954 when the destroyer SAS Simon van der Stel also visited Rotterdam. From there the Drakensberg sailed to Zeebrugge in Belgium (the first time that a South African warship visited that country), staying from 6 to 8 July, and then to Rouén in France (9-17 July), to form part of the La Armada de la Liberté, celebrating the 50th anniversary of the liberation of France from Nazi occupation. The armada consisted of at least 50 warships and tall ships, and sailed down the River Seine from Rouén to Le Havre on 17 July, with about six million people watching from the banks. The next stop was London, where the ship arrived on 18 July and was berthed at Canary Wharf (the first ever South African warship to visit the British capital).

Members of the crew took part in a wreath-laying ceremony at the Cenotaph and the ceremony at Westminster Abbey marking South Africa's readmittance to the Commonwealth. South Africa once again became part of the Commonwealth on 17 July 1994, after an absence of more than 33 years, but the ceremonies were held on 20 July. ${ }^{83}$

Leaving London on 28 July, the Drakensberg the next day reached the spot near the Isle of Wight where the troopship Mendi sank in 1916. The Drakensberg also visited Portsmouth and then sailed to Cadiz in Spain (staying 26-28 July), São Tomé Island (anchoring off the $\mathrm{i}$ and, 6-7 August), anchored off the island of Principé (7-8 August), and anchored off $\mathrm{Bi}$ so Island, Equatorial Guinee ( 9 August); then visited Libreville in Gabon (10-12 August where three Gabonese officers were taken on board to attend courses in South Africa. he Drakensberg arrived back in Simon's Town on 18 August 1994, after being away fo 92 days. The total distance sailed was about 20100 nautical miles. This cruise was a re ounding success, and the friendships made and renewed would take South Africa and the new South African National Defence Force (SANDF) into a new era of international c -operation and success. ${ }^{84}$ In less than three months, the ship had visited

82 Navy News 13, June 1994, p. 18 and Oct. 1994, p. 13; The Daily News, 6.6.1994, p. 2; Salut 1(6), Oct. 1994, p. 26.

83 Salut 1(6), Oct. 1994, pp. 27-28; Navy News 13, June 1994, p. 18 and Oct. 1994, p.14;Die Volksblad, 19.7.1994, p. 3 .

84 Public Relations Directorate, S.A. Naval Headquarters, Pretoria: S.A. Navy deployments Jan. 1990-Jun. 1997, p.14; information supplied by Capt. P.S. Barnard; Navy News 13, Oct. 1994, pp. 15-16; Ships Monthly 30(2), Feb. 1995, p. 18. As far as the sinking of the Mendi is concerned, see e.g. I. Gleeson, The unknown force: black, Indian and coloured soldiers through two world wars (Rivonia, 1994), pp. 1-8 and N. Clothier, Black valour: the South African Native Labour Contingent, 1916-1918, and the sinking of the 'Mendi' (Pietermaritzburg, 1987), pp. 39-100. 
more countries and harbours than any of the SAN's other grey diplomats had during a single cruise. The Drakensberg, conceived and commissioned in the era of apartheid and sanctions, became the first and foremost grey diplomat of the new democratic South Africa.

On 2 September 1994 SAS Walvisbaai (under the command of Cdr A. Kamfer) became the first "Ton" class minesweeper in more than twenty years to act as a grey diplomat when - accompanied by the diving support and torpedo recovery ship SAS Fleur (Lt Cdr S.M. Pederson) - she left Simon's Town to pay courtesy calls at islands in the Indian Ocean. The main purpose of the cruise was to strengthen previous contacts made with foreign naval forces, and to promote the SANDF's strategy of collective security in South Africa's maritime operations theatre. Other objectives were, inter alia, to provide sea training for personnel on small warships, to boost the morale of the Mine Countermeasures Flotilla personnel and to promote the capability and image of the S.A. Navy nationally and internationally. After calling at Durban (5-6 September), the vessels arrived at Tamatava on the east coast of Madagascar on 11 September for a three-day stay. From there they sailed on 13 September to Port Louis on Mauritius (staying 15-17 September), where on 17 September the Beachcomber yacht race started, with the Walvisbaai taking 23 visitors out to sea and Fleur firing the saluting gun which started the race. The next and last stop was at the French possession of Reunion, where they arrived at Port des Galets on 18 September. The French warships Floréal (frigate) and Albatros (patrol vessel) acted as hosts for the Walvisbaai and Fleur respectively, and the frigate conducted exercises with the South African vessels, including helicopter operations. During the passage home (having left Reunion on 20 September) the South African warships acted as communication vessels for the yachts participating in the race from Mauritius to Durban, arriving back in Durban on 25 September, sailing again the following day, and arrived in Simon's Town on 29 September, after sheltering from bad weather for six hours in Plettenberg Bay. It was the first time that such small vessels of the South African Navy had in peace-time been deployed so far from their home country without the support of a larger vessel. Without doubt, "Operation Maroela" had been a resounding success. ${ }^{85}$

The last cruise to a foreign country by a South African warship in 1994 was in September and October when SAS Outeniqua (Capt. Jan Vorster) went to Dar es Salaam in Tanzania to offload some 8000 tons of maize-meal and other food for the Rwandan refugees who had fled their country following the bloodshed caused by the civil war. Although "Operation Southern Virtue/Heaven" was in the first place a relief operation, the cruise afforded the Navy the opportunity of showing the South African flag for the first time in

85 Report of proceedings: Operation Maroela 02 tot 29 September 1994; Navy News 13, Nov.-Dec. 1994, pp. $12-$ 13; Sunday Times, 16.10.1994, p. 4; Public Relations Directorate, S.A. Naval Headquarters, Pretoria: S.A. Navy deployments Jan. 1990-Jun. 1997, p.15. 
32 years in Tanzania. The ship left Simon's Town on 17 September, arrived in Dar es Salaam on 28 September, departed on 4 October, and arrived back in Simon's Town on 11 October $1994 .^{86}$ The previous South African naval visitor to Dar es Salaam was SAS Jan van Riebeeck in 1952.

As had become customary over the previous few years, SAS Drakensberg was deployed on a long overseas visit in 1995. This time the primary aim of the cruise ("Operation Western Star") was to transport cargo for Armscor and affiliated companies to Abu Dhabi in the United Arab Emirates for the International Defence Industry Expo which was to be held from 19 to 23 March (IDEX'95). The cargo consisted of a Rooikat armoured car, a Nyala and a Caspir armoured personnel carrier, and two Bateleur multiple rocket launchers. ${ }^{87}$ It would be the first time that a South African warship would visit that area, and consequently the opportunity would be utilised to call at other ports and to pay diplomatic visits.

Under the command of Capt. Preston Barnard, the Drakensberg left Simon's Town on 15 February 1995, arrived in Durban on 17 February, loaded the cargo, and sailed again the following day. The ship arrived in Port Mina Zayed, the port of Abu Dhabi (in the United Arab Emirates) on 2 March and offloaded the equipment for the exhibition. On 4 March the ship left for Karachi in Pakistan, arriving on 6 March, the first time that a South African warship visited that country. The Drakensberg left again on 9 March, arriving back in Port Mina Zayed two days later, and now staying for nearly two weeks. While IDEX'95 was in progress, the Drakensberg was one of eighteen naval vessels present, including ships from the USA, Britain, Canada and Germany. On 24 March the Drakensberg left for Bombay in India (28-30 March), reciprocating a visit by two Indian warships to South Africa in December 1994. On 2 April the grey diplomat was back in Port Mina Zayed to take on board the military hardware exhibited at IDEX'95. Because of a broken clutch that had to be repaired, a visit to Bahrain had to be cancelled. From Abu Dhabi the ship sailed on 7 April to Muscat in Oman (9-10 April), and then returned to Simon's Town, via Durban (20-21 April), arriving back on 23 April 1995. ${ }^{88}$

In April 1995, two South African "River" class minehunters visited Namibia, extending a South African hand of friendship to a neighbour, and reaffirming South Africa's commitment to regional co-operation, regional peace and regional security. The SAS Umzimkulu (under the command of Cdr A. Geldenhuys) and SAS Umgeni (Lt-Cdr L.J. du Plessis) left Simon's Town on 2 April to conduct a fishery protection patrol off the West Coast. They then paid a goodwill visit to Lüderitz (5-6 April) and Walvis Bay (7-9 April), ters, Pretoria: S.A. Navy deployments Jan. 1990-Jun. 1997, p. 15.

87 Navy News 14, May 1995, p. 12; information supplied by Sub-Lt D.J. Olivier, SAS Drakensberg.

88 Navy News 14, May 1995, pp. 12-14. 
and arrived back in Simon's Town on 13 April $1995{ }^{89}$ This was the first time since Walvis Bay was handed over to Namibia on 28 February 1994 that South African naval vessels had paid a visit to the port.

The aims of "Operation Palm Beach" (July-August 1995) were, inter alia, to further improve relations and naval co-operation between the RSA on the one hand and Mozambique and Tanzania on the other hand; to train the Transportable Logistic Support (TLS) personnel and evaluate the Outeniqua's ability to provide TLS for units on deployment; to reconfirm the Navy's ability to operate submarines under tropical conditions; and to provide midshipmen with practical training in navigation and seamanship. The task-force comprised SAS Outeniqua (under the command of Capt. A.G. Absolom, with an Alouette helicopter and two Namacurra harbour patrol boats on board), the submarine SAS Maria van Riebeeck (Cdr D.R. W.H.O Teuteberg), and the strike craft SAS Oswald Pirow (Cdr C.R. Sharwood) and SAS Kobie Coetzee (Cdr D.R. Faure). ${ }^{90}$ In 1997 the latter two vessels were renamed SAS René Sethren and SAS Job Masego respectively.

Maria van Riebeeck sailed from Simon's Town on 30 June 1995 and sailed direct to Maputo. SAS Outeniqua sailed from Simon's Town on 1 July and arrived in Durban on 3 July. The three surface ships sailed from Durban on 5 July. All four units entered Maputo harbour on 6 July. The same evening the South African ambassador to Mozambique, $\mathrm{Mr}$ Mangisi Sitha, held a dinner on board the combat support ship for members of the diplomatic corps and the Mozambican defence force. On 7 July the two Namacurras gave a harbour protection demonstration. The next day (the 100th anniversary of the opening of the Delagoa Bay railway line), Mozambican president Joachim Chissano visited the task group, and later attended an air show at Maputo International Airport in which the South African Air Force also took part. The Navy vessels were open to the public. ${ }^{91}$

On 9 July the slower submarine left port en route to Dar es Salaam, with the faster surface ships following the next day, conducting live firing exercises and RAS underway. All four units berthed in Dar es Salaam on 17 July. The following day Capt. Absolom accompanied the South African High Commisioner in Tanzania and the chief of the Tanzanian Navy to a wreath-laying ceremony at the Commonwealth War Graves Memorial. Once again the ships were open to visitors and served as venues for various diplomatic functions. The task force departed on 20 July, once again carrying out various RAS exercises. The two Mozambican officers who had accompanied the squadron from Maputo to Dar es Salaam, were flown back to Maputo from Mozambican waters, and the task force

89 Navy News 14, Sept. 1995, p. 4; Public Relations Directorate, S.A. Naval Headquarters, Pretoria: S.A. Navy deployments Jan. 1990-Jun. 1997, p. 17.

90 Salut 2(10), Oct. 1995, pp. 4, 34-36.

91 Ibid., pp. 34-35; Ad Astra 18(8), Aug. 1995, p. 27; information supplied by Cdre S.K. Stead. As far as the Delagoa Bay railway line is concerned, see e.g. R.C. de Jong et al., The buildings, steam engines and structures of the Netherlands South African Railway Company (Johannesburg, 1988), passim. 
arrived back in Durban to a ceremonial welcome on 25 July. The Simon's Town ships were back at their base on 30 July. ${ }^{92}$

On 10 March 1996 the minesweeper SAS Walvisbaai (under command of Cdr J.H. Steenkamp) and diving support and torpedo recovery ship SAS Fleur (Lt-Cdr D. Wolfaardt) - i.e. the same ships that had visited islands in the Indian Ocean in 1994 - left Simon's Town and visited Walvis Bay (13 March) on their way to Port Gentil in Gabon. An intended visit to Luanda was cancelled because of a diplomatic hitch. This led to severe water restrictions being imposed on board the vessels. Arriving in Gabon on 22 March on a goodwill visit, the ships served as venues for diplomatic functions aimed at strengthening the ties between the two countries and navies. Leaving again on $25 \mathrm{March}$, the South African vessels escorted the Gabonese LST President el Hadj Omar Bongo to Cape Town where it was repaired and re-equipped by Denel. On passage to Simon's Town the vessels once again visited Walvis Bay (30 March-2 April). During "Operation Harmatten Wind" the two South African ships lay three drifting weather buoys for the Department of Environmental Affairs and Tourism: one opposite Walvis Bay, one on crossing Lattitude $15^{\circ} \mathrm{S}$, and one opposite Luanda. ${ }^{93}$

On 7 and 8 August 1996 eleven countries' naval chiefs or their representatives attended a meeting in Durban chaired by Vice-Adm. Robert Simpson-Anderson. The countries represented were members of the Southern African Inter-State Defence and Security Committee (ISDSC), formed to promote regional co-operation with reference to defence and security. The countries represented at the August meeting constituted the Standing Maritime Committee Southern African States which was in inaugurated in 1995 to facilitate naval co-operation between member states. ${ }^{94}$

The most extensive and most important flag-showing and training cruise of 1996 and the last cruise of its kind relevant to this study - was without doubt the visit of our foremost grey diplomat (SAS Drakensberg) to the USA, twenty years after the frigate SAS President Kruger had been the last South African naval visitor to those shores. While attending the Thirteenth International Naval Power Symposium at the US Navy College at Rhode Island in November 1995, Vice-Adm. Robert Simpson-Anderson had been invited to send a ship to take part in the next annual joint naval exercise. This invitation was duly accepted, and the Drakensberg left Simon's Town on 14 June 1996 under the command of Capt. Robert Myers. On board were 146 crew members, including three women as well as an Oryx helicopter. ${ }^{95}$

92 Salut 2(10), Oct. 1995, pp. 35-36; The Mercury, 4.7.1995, p. 2.

93 Die Burger, 6.4.1996, p. 3; Navy News 15, June-July 1996, p. 17; Public Relations Directorate, S.A. Naval Headquarters, Pretoria: S.A. Navy deployments Jan. 1990-Jun. 1997, p.18; Line-book: SAS Fleur.

94 Navy News 15, Sept, 1996, p. 19.

95 Salut 3(2), Feb. 1996, p. 18 and 3(11), Nov. 1996, p. 59. 
The Drakensberg crossed the South Atlantic, placing two weather buoys in the ocean en route and on 24 June anchored off Rio de Janeiro (Brazil) to take on board the Navy's yacht Southern Maid that had been damaged during the 1995 Cape to Rio race and was unable to sail back home. Shortly after arriving at the US Naval Base at Roosevelt Roads, near San Juan in Puerto Rico on 5 July, the Drakensberg and other assembled warships had to leave port in an effort to avoid Hurricane Bertha. After the hurricane had passed near the island, the ships returned and began preparations for "Operation Unitas", as the naval exercise was code-named. Some 26 warships from seventeen navies participated, going through tactical warfare, anti-submarine, anti-aircraft and RAS exercises. The Drakensberg acquitted herself very well, proving herself to be every bit as professional as units from larger and wealthier navies. ${ }^{96}$

On 21 July the Drakensberg left Puerto Rico and sailed to Norfolk, Virginia, staying from 25 to 29 July, and from there to New York, berthing next to the museum ship (destroyer) USS Edson at the Intrepid Sea-Air-Space Museum on 3 August. From there the ship sailed to Newport to load a weather radar and 40 weather buoys for the Department of Environmental Affairs. On 6 August the Drakensberg departed, and sailed across the Atlantic to Dakar in Senegal, arriving on 15 August, departing on 18 August. The last South African warships to visit that port were the minesweepers SAS Mosselbaai and SAS Walvisbaai and the SDB SAS Oosterland in 1959, when it was still a French possession. The next stop was Tema in Ghana (22-24 August), where the usual public relations exercises took place, and then the ship sailed to the island of Principé, anchoring off the island (25-27 August). The Drakensberg arrived back in Simon's Town on 3 September after a very successful cruise lasting 81 days. ${ }^{97}$

\section{CONCLUSION}

The primary role of the South African Navy must always be to conduct operations in defence of the RSA, its citizens and interests, but in times of peace the Navy has an equally important role to play. Peacetime operations include search and rescue, relief operations, assistance to state or provincial authorities, regional assistance operations, and flag-showing cruises. From 1946 to 1996 South African warships went on foreign deployments on at least 68 occasions, including delivery voyages. Not all of them were planned as primarily flag-showing cruises, but all the visits were in one way or other a flag-showing exercise. From 1946 to 1979 at least 21 of the 41 cruises can be regarded as being primarily flagshowing cruises, while fifteen were delivery (maiden) voyages. Since 1987 (to 1995) twelve of the 27 cruises were more or less bona fide flag-showing cruises, while four of the others

Ibid., pp. 15-18; Salut 3(11), Nov. 1996, pp. 58-59. 
were primarily relief operations (e.g. taking food to areas where refugees were cared for, like when the Drakensberg took food to Bangladesh, Turkey and Mozambique in 1992), and three were cruises that were planned around some form of assistance given to a particular government department or to Armscor (e.g. taking equipment to an arms exhibition, like the Drakensberg to Chile in 1988). In the light of budgetary constraints, the Navy can no longer afford the luxery of tailor-made flag-showing cruises, but wherever other functions offer the opportunity, it is eagerly taken to use its ships as grey diplomats. All cruises were (and are) in varying degrees also training cruises, and as such they are always valuable and cost-effective.

Since 1946, at least 95 ports in at least in 45 countries on all six the continents have been visited by South African warships during 68 flag-showing cruises, with Lisbon in Portugal the port being visited on most occasions, namely sixteen times, and Angola the country visited on most accasions, namely seventeen times, albeit when the country was still a Portuguese colony. In the course of the fifty years under consideration (1946-1996), 47 out of 48 major warships in commission in the South African Navy during that period were employed as grey diplomats during the 68 above-mentioned cruises, namely all three the submarines, both destroyers, all seven frigates, thirteen out of fourteen patrol vessels (eight out of nine strike craft and all five seaward defence boats), all twelve minesweepers, all four minehunters, all three combat support vessels, both the hydrographic survey ships, as well as the diving support and torpedo recovery vessel. As a matter of fact, of the Navy's 48 major warships in service since 1946, only the SAS Adam Kok (ex SAS Frederic Creswell) had until 1996 never been on a flag-showing cruise.

From 1987 to 1996 nineteen warships were used as grey diplomats (compared to the 31 in the years from 1946 to 1979). The most active grey diplomats have been SAS Drakensberg (twelve flag-showing cruises) SAS Tafelberg (ten) and SAS President Pretorius (six). While destroyers and frigates were the most important grey diplomats in the years 1948 to 1976, combat support vessels have taken over that role since 1987. Since 1990 the South African Navy has tried to undertake at least one extensive visit abroad every year, backed up by at least two shorter deployments. On two occasions (in 1969 to Angolan ports and in 1993 to South America) the SAN sent a task force of five units on an overseas flag-showing deployment; the 1993 task force being (relatively speaking), the strongest force ever sent abroad.

From the review of the Navy's flag-showing cruises since 1946, it is clear that a number of phases can be identified:

1946-1973. Normal relations with most countries in the Western World, with a total of 37 flag-showing cruises, including sixteen visits to European colonial possessions in Africa, six transoceanic deployments (to South America, Europe and to Australia), and visits to many ports during the delivery voyages of 26 new vessels for the South African Navy. 
1974-1979.

1980-1986.

1987-1993.

1994-present. With the birth of a democratic South Africa in April 1994, the country was officially welcomed back on all fronts as a respected member of the international community, a major military power in Africa, and an important maritime power in the Southern Hemisphere. In a period of three years $(1994,1995,1996)$, at least 29 ports in at least 23 countries were visited by South African warships during eight flag-showing cruises, most of them for the first time by an SAN vessel. So, after years of isolation, the SAN's grey diplomats in a short space of time played a major role in re-establishing the ties of friendship that existed between the Navy and several foreign navies, but also established several new ties, e.g. with certain African, Asian and South American countries.

Ironically, now that the RSA has been welcomed back by the international community, the country does not have any traditional grey diplomats, i.e. frigates or bigger combat vessels, and primarily has to use support vessels (SAS Drakensberg and SAS Outeniqua) in that role. The Navy's last frigate was decommissioned in 1985, and since then all efforts to acquire new (or good second-hand) combat vessels have been unsuccessful, the problems since 1994 surrounding the acquisition of four new corvettes being the latest in a long line of demoralising frustrations. ${ }^{98}$ It is to be hoped that the SAN will as soon as possible acquire at least four corvettes (or preferably frigates), not only to be used as grey diplo-

As far as the corvette-saga is concerned, see e.g. The Natal Mercury, 5.1.1994, p. 2 and 18.5 .1995 , p. 2; Sunday Times, 8.5.1994, p. 4 and 6.11 .1994 , p. 8. By far the best review of the efforts to procure corvettes, is that by Edmonds and Mills, pp. 14-16, 29-63,68. 
mats, but primarily as guardians of South Africa's coasts, harbours and extensive maritime resources.

Because a warship is both a reflection and projection of the state it represents, it is important that the ships that are acquired by the SAN are not undersized, under-equipped or under-powered. South Africa's national pride is at stake. Warships can generate a sense of pride neither army equipment nor aircraft (which cannot be visited or experienced like a ship) can. The more the RSA moves out of diplomatic isolation, the more South Africa need warships to underpin its diplomatic efforts. ${ }^{99}$ In the meantime, the Navy's two combat support vessels, and especially SAS Drakensberg, will have to be used as grey diplomats, always within the context of the Navy's doctrines.

The importance of the South African Navy's grey diplomats cannot be disputed. They have proved that in times of peace, the Navy's role in the support of the state's diplomatic initiatives encompasses a wide range of activities. After all, a South African warship is South African territory afloat and its presence in foreign waters sends a strong signal of support to South Africa's allies. The review of the past 50 years' diplomatic activities by the Navy has shown to what extent contact with other navies, countries and peoples have been made, fostering mutual respect and insight, bringing about co-operation and joint training opportunities, supplying relief and other assistance, whether in areas where people suffered from the results of natural disasters or as a consequence of political upheaval. Of particular importance in this regard has been the role played by the South African Navy in the African context, as well as in the South Atlantic and Indian Ocean rim areas.

The past few years have indicated what the South African Navy can achieve with limited resources. Hopefully the Navy will in future have at its disposal the necessary funds and ships, including frigates - to meet all the demands of its mission statement, including its diplomatic role. After all, if one looks back over the history of the Navy's first 75 years (1922-1997), it is the role played by its 50 grey diplomats during about 70 cruises that stands out as perhaps the Navy's most significant achievement.

Edmonds and Mills, p. 73. 